\title{
Diabetic nephropathy - complications and treatment
}

This article was published in the following Dove Press journal: International Journal of Nephrology and Renovascular Disease 15 October 2014

Number of times this article has been viewed

\author{
Andy $\mathrm{KH} \mathrm{Lim}{ }^{1-3}$ \\ 'Department of Nephrology, Monash \\ Medical Center, Monash Health, \\ 2Department of General Medicine, \\ Dandenong Hospital, Monash Health, \\ ${ }^{3}$ Department of Medicine, Monash \\ University, Clayton, VIC, Australia
}

Correspondence: Andy Lim Department of Nephrology, Monash Medical Center, 246 Clayton Road,

Clayton, VIC 3168, Australia

Tel +6I 395946666

Fax +6I 395946730

Email andy.lim@monash.edu
Abstract: Diabetic nephropathy is a significant cause of chronic kidney disease and end-stage renal failure globally. Much research has been conducted in both basic science and clinical therapeutics, which has enhanced understanding of the pathophysiology of diabetic nephropathy and expanded the potential therapies available. This review will examine the current concepts of diabetic nephropathy management in the context of some of the basic science and pathophysiology aspects relevant to the approaches taken in novel, investigative treatment strategies.

Keywords: diabetes, diabetic nephropathy, albuminuria, kidney disease, inflammation

\section{Introduction}

Background

Diabetic nephropathy (DN) or diabetic kidney disease is a syndrome characterized by the presence of pathological quantities of urine albumin excretion, diabetic glomerular lesions, and loss of glomerular filtration rate (GFR) in diabetics. Diabetes may be classified as type 1 (autoimmune $\beta$-cell destruction and absolute insulin deficiency), type 2 (relative insulin deficiency and resistance), and other types (eg, pancreatic disease).

\section{Epidemiology}

The prevalence of diabetes is phenomenal and the projections are staggering. When one considers the morbidity, mortality, and cost of health care, the burden of the diabetes epidemic becomes apparent. Worldwide, the prevalence of diabetes was estimated at 171 million in 2000, increasing to 382 million in 2013; and is projected to reach 592 million by 2035 . This represents $8 \%-10 \%$ of the global population, resulting in at least 548 billion dollars in health expenditure on diabetes care. Type 2 diabetes constitutes about $85 \%-95 \%$ of all diabetes cases. ${ }^{1}$ In the US alone for $2011,25.8$ million children and adults have diabetes with another 79 million having a prediabetic state. ${ }^{2}$

The diabetes epidemic has resulted in DN becoming the most frequent cause of end-stage renal disease (ESRD) in most countries. In 2009-2011, diabetes was the primary cause of ESRD in about $60 \%$ of patients in Malaysia, Mexico, and Singapore. Countries with an ESRD incidence of 40\%-50\% include Israel, Korea, Hong Kong, Taiwan, Philippines, Japan, the US, and New Zealand. ${ }^{2}$ The incidence of ESRD due to diabetes also rises in the older age group. In 2011, the incident rates of ESRD due to diabetes in the US were 44, 266, and 584 per million for the age groups 20-44, 45-64, and 65-74 years, respectively. A similar finding was noted in the AusDiab study of 11,247 diabetic Australians. ${ }^{3}$ Thus, the reason for this boom in diabetes-associated 
ESRD is the increasing prevalence of diabetes and the aging population.

\section{Risk factors}

Not all diabetics develop DN and in those who do, progression is variable. The main modifiable risks are hypertension, glycemic control, and dyslipidemia. Data from the Joslin Diabetes Center, Steno Diabetes Center, and AusDiab studies also strongly implicate smoking as a risk factor for DN. ${ }^{3-5}$ The main unmodifiable risks are age, race, and genetic profile. DN is more likely to develop in patients with a family history of DN. ${ }^{6-8}$ Certain racial groups are also at higher risk, such as African Americans, Mexican Americans, and Pima Indians..$^{9,10}$ One study suggested that males had an increased risk of DN. ${ }^{11}$

A meta-analysis of studies identified 24 genetic variants in 16 genes which are associated with DN. These include: $A C E, A L R 2, A P O C 1, A P O E, E P O, e N O S, H S P G 2, V E G F$, FRMD3, CARS, UNC13B, CPVL/CHN2, and GREM1. In a subgroup of type 2 diabetic Asians, ELMO1, CCR5, and $C N D P 1$ were also relevant. ${ }^{12}$ Other meta-analyses implicated polymorphisms of ADIPOQ, PAI-1, TGF $\beta 1$, and PPAR $\gamma$ in the development of DN. The nature of the polymorphism varies with ethnicity. ${ }^{13-15}$ The complexity of genetic studies in $\mathrm{DN}$ is discussed in a review by Mooyaart. ${ }^{16}$

\section{Diagnosis Stages and natural history}

Incipient nephropathy is the initial presence of low but abnormal amounts of urine albumin, referred to as microalbuminuria (persistent albuminuria at level 30-299 mg/24 hours). Overt nephropathy or macroalbuminuria (persistent albuminuria at level $\geq 300 \mathrm{mg} / 24$ hours) develops after many years in type 1 diabetes but may be present at the time of diagnosis of type 2 diabetes. Patients who progress to macroalbuminuria are more likely to develop ESRD. ${ }^{11}$ The natural history depends on the type of diabetes.

In untreated type 1 diabetics, approximately $80 \%$ of patients with sustained microalbuminuria increase their albumin excretion by $10 \%-20 \%$ per year until overt nephropathy develops, which normally takes $10-15$ years. With the development of overt nephropathy, the GFR declines at a rate of 2-20 mL/minute/year and ESRD develops in $50 \%$ within 10 years and in $75 \%$ by 20 years. ${ }^{17}$ Structural changes can precede albuminuria and reduced GFR, with glomerular basement membrane thickening and mesangial expansion, can be detected as early as $2-8$ years after onset of diabetes. ${ }^{18}$
In type 2 diabetics, more patients have $\mathrm{DN}$ at the time of diagnosis of diabetes as type 2 diabetes can go unrecognized for years. The AusDiab study of diabetic Australians showed that albuminuria is common among patients with established diabetes, is present before the onset of diabetes, and becomes more prevalent with worsening glucose tolerance. ${ }^{3}$ About $20 \%-40 \%$ of type 2 diabetics with microalbuminuria progress to overt nephropathy; and about 20\% will develop ESRD after the development of overt nephropathy. ${ }^{17,19}$

\section{Screening for DN}

Most guidelines recommend screening with a spot urine albumin/creatinine ratio (ACR; normal $<30 \mathrm{mg} / \mathrm{g}$ creatinine), from either first morning (preferred) or random specimens. An abnormal result is repeated once or twice over a few months for consistency. This is coupled with an assessment of renal function, using the Modification of Diet in Renal Disease or Chronic Kidney Disease Epidemiology Collaboration formulas for estimated GFR (eGFR) in order to stage chronic kidney disease (CKD). ${ }^{20,21}$ Screening begins at diagnosis of type 2 diabetes and usually 5 years after onset of type 1 diabetes. Timed collections can also be utilized and will average out diurnal variations in albumin excretion (normal $<20 \mu \mathrm{g} /$ minute).

\section{Renal biopsy}

The routine use of renal biopsy to confirm $\mathrm{DN}$ is much debated. Many nephrologists do not biopsy patients with classic features such as retinopathy, duration of diabetes $>10$ years, slow decline in GFR, gradual progression of proteinuria, and lack of active urinary sediment. Without standardized criteria, there may be significant variations in epidemiology. An Italian study of 393 type 2 diabetics highlighted this point. In centers with an unrestricted biopsy policy, the rate of finding an underlying glomerulonephritis was lower than those centers with a restricted biopsy policy $(33 \%$ versus $57 \%$ ). The unrestricted policy resulted in a greater proportion of patients found to have glomerulonephritis rather than diabetic glomerulosclerosis. ${ }^{22}$ The prevalence of specific disease in the population can also affect the biopsy decision. In a Chinese study of 51 type 2 diabetics with $>1 \mathrm{~g} /$ day proteinuria, one-third of patients had nondiabetic disease, predominantly IgA nephropathy. ${ }^{23}$ The largest study to date looked at 620 biopsies from type 1 and 2 diabetics, with a median duration of diabetes of 10 years. Overall, 37\% of patients had isolated DN, 36\% had isolated nondiabetic disease, and $27 \%$ had nondiabetic disease superimposed on DN. 
The duration of diabetes $>12$ years was the best predictor for isolated DN. Interestingly, $43 \%$ of biopsies with DN demonstrated superimposed acute tubular necrosis. ${ }^{24}$ Thus, a renal biopsy is useful to exclude acute tubular injury and diseases amenable to specific therapy.

\section{Biomarkers}

There are limitations in using albuminuria as a marker of DN as many patients experience GFR loss without deterioration in albuminuria and even normoalbuminuria. ${ }^{25}$ In fact, histologically proven advanced diabetic glomerular lesions can develop despite normoalbuminuria. ${ }^{26}$ Furthermore, low-grade albuminuria is a lesser predictor of disease progression than macroalbuminuria. ${ }^{27}$ Therefore, there is interest in finding biomarkers to detect DN earlier and identify progression risk. There is also interest in urine microRNA profiling but studies are fairly preliminary. ${ }^{28,29}$ The most promising biomarker currently is serum TNF- $\alpha$ receptor levels, which may predict progression of CKD and ESRD, in type 1 and type 2 diabetics. In type 2 diabetics, the TNF- $\alpha$ receptor level showed prognostic value in addition to albuminuria. ${ }^{30,31}$ Serum uric acid is another biomarker which may also be pathogenic (discussed later). Studies of tubular biomarkers have been conflicting (Table 1). The larger studies have not shown that these biomarkers offer additional value on top of traditional prediction models. More work is needed to clarify the role of biomarkers in clinical practice.

\section{Pathogenesis}

\section{Pathology and pathophysiology}

$\mathrm{DN}$ is characterized by structural and functional changes. In glomeruli, there is mesangial expansion, thickening of the basement membrane, and, characteristically, nodular glomerulosclerosis (Kimmelstiel-Wilson nodules). In early $\mathrm{DN}$, tubular hypertrophy is present but eventually interstitial fibrosis with tubular atrophy develops, along with arteriolar hyalinosis. In advanced cases, there is an infiltrate of macrophages and T-lymphocytes. Ultrastructurally, there is podocyte loss and reduced endothelial cell fenestration. ${ }^{32,33}$ These characteristic pathological changes are shown in Figure 1. Functionally, there is early glomerular hyperfiltration and increased albumin excretion; and with advancing nephropathy, increasing proteinuria and declining GFR. A brief description of the functional and cellular pathology is provided below. Although it is conceptually easier to describe these pathways individually, these pathways overlap and interact with one another in vivo, and enhance one another's biophysiological effects (Figure 2).

Table I Tubular biomarkers

\begin{tabular}{|c|c|c|c|c|}
\hline Biomarker & Source & Cohort (size) & Key points & Reference \\
\hline \multirow[t]{3}{*}{ KIM-I } & Blood & Type I (I24) & $\begin{array}{l}\text { Baseline KIM-I in proteinuric ( }>500 \mathrm{mg} / \text { day) patients predicted rate } \\
\text { of eGFR loss and ESRD during } 5-15 \text { years of follow-up. }\end{array}$ & Sabbisetti et al ${ }^{208}$ \\
\hline & Urine & Type I (63) & KIM-I associated with decline in GFR but not independent of albuminuria. & Nielsen et $\mathrm{al}^{209}$ \\
\hline & Urine & Type 2 (978) & $\begin{array}{l}\text { Urine } \mathrm{KIM}-\mathrm{I} / \mathrm{Cr} \text { associated with faster decline in GFR during } 4 \text { years follow- } \\
\text { up but offered no additional prognostic information to albumin/Cr ratio. }\end{array}$ & Conway et $\mathrm{a}^{210}$ \\
\hline \multirow[t]{3}{*}{ NGAL } & Serum/urine & Type I (50) & $\begin{array}{l}\text { Elevated before microalbuminuria. Serum NGAL correlated with } \mathrm{HbA}_{\mathrm{lc}} \\
\text { and urine NGAL correlated with albuminuria. }\end{array}$ & Lacquaniti et al ${ }^{211}$ \\
\hline & Urine & Type I (63) & NGAL associated with decline in GFR but not independent of albuminuria. & Nielsen et $\mathrm{a}^{209}$ \\
\hline & Serum/urine & Type 2 (140) & No correlation with eGFR. & Chou et $\mathrm{a}^{212}$ \\
\hline \multirow[t]{8}{*}{ L-FABP } & Urine & Type I $(1,549)$ & Patients ranged from normoalbuminuria to macroalbuminuria. & Panduru et $\mathrm{al}^{213}$ \\
\hline & & & Urine L-FABP/Cr ratio at baseline predicted progression of $\mathrm{DN}$ but adding & \\
\hline & & & L-FABP to albumin excretion did not improve prediction model. & \\
\hline & Urine & Type I (277) & Urine L-FABP predicted progression of albuminuria or death. & Nielsen et $\mathrm{al}^{214}$ \\
\hline & Urine & Type I (63) & L-FABP not related to decline in GFR. & Nielsen et $\mathrm{a}^{209}$ \\
\hline & Serum/urine & Type 2 (140) & $\begin{array}{l}\text { Serum L-FABP correlated with baseline eGFR but did not predict } \\
\text { decline in eGFR. }\end{array}$ & Chou et $\mathrm{al}^{212}$ \\
\hline & Urine & Type $2(6 \mid 8)$ & $\begin{array}{l}\text { Japanese patients without overt proteinuria and serum creatinine } \\
\leq 1.0 \mathrm{mg} / \mathrm{dL} \text { followed for median of } \mathrm{I} 2 \text { years. Urine L-FABP in the } \\
\text { highest tertile was associated with } 50 \% \text { decline in eGFR or progression } \\
\text { to eGFR }<30 \mathrm{~mL} / \text { minute } / \mathrm{m}^{2} \text {. }\end{array}$ & Araki et $\mathrm{a}^{215}$ \\
\hline & Urine & Type 2 (140) & High L-FABP associated with progressive albuminuria, ESRD, or hemodialysis. & Kamijo-lkemori et $\mathrm{a}^{216}$ \\
\hline Cystatin C & Urine & Type 2 (237) & $\begin{array}{l}\text { Urine cystatin } \mathrm{C} / \mathrm{Cr} \text { ratio associated with decline in eGFR, with the upper } \\
\text { tertile of levels associated with progression to stage } 3 \mathrm{CKD} \text { or higher after } \\
20 \text { months follow-up. }\end{array}$ & Kim et $\mathrm{al}^{217}$ \\
\hline
\end{tabular}

Abbreviations: CKD, chronic kidney disease; $\mathrm{Cr}$, creatine; eGFR, estimated glomerular filtration rate; ESRD, end-stage renal disease; GFR, global filtration rate; $\mathrm{HbA}_{\mathrm{Ic}}$, hemoglobin $\mathrm{A}_{\mathrm{Ic}}$. 

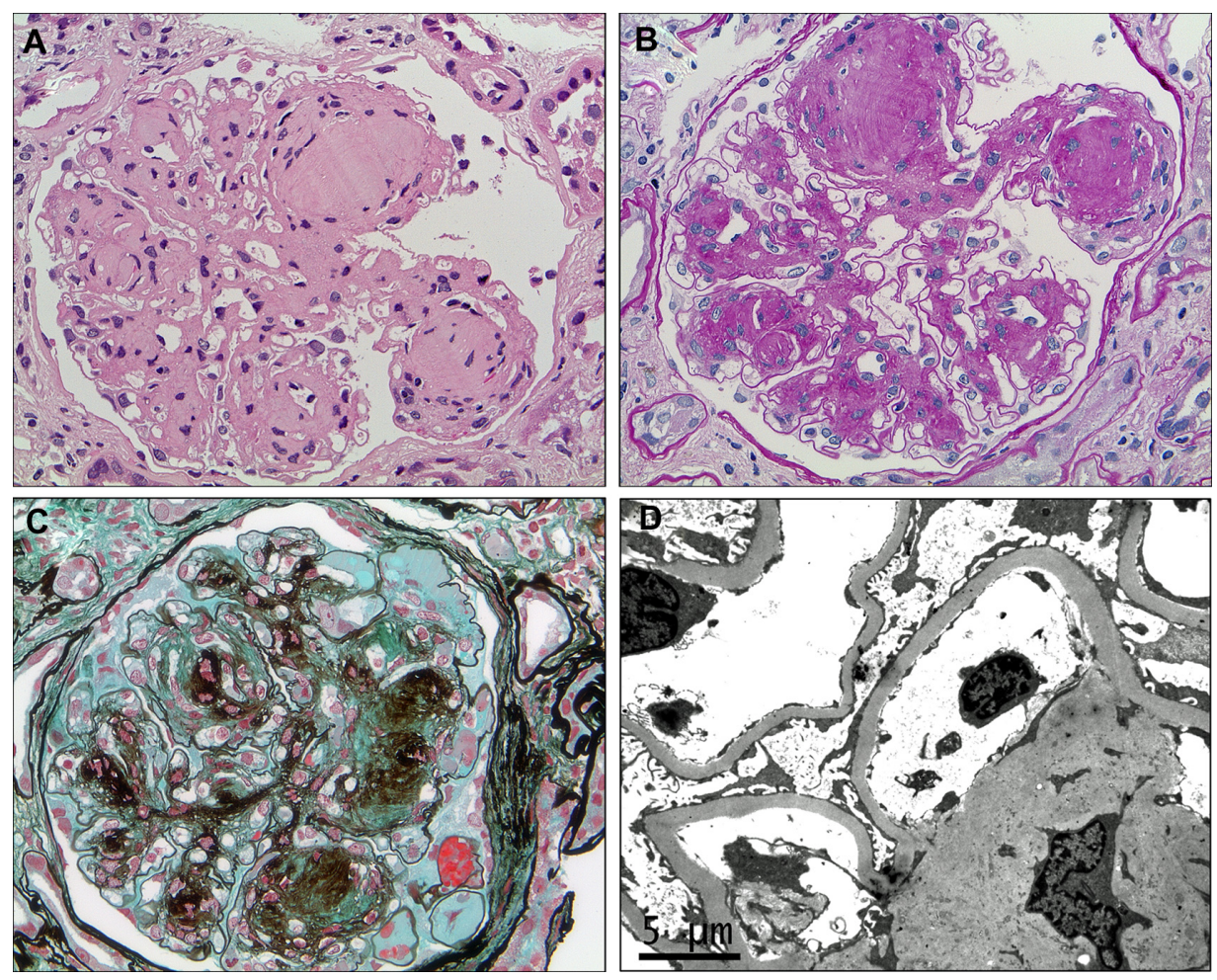

Figure I Characteristic histological features of diabetic nephropathy.

Notes: In advanced diabetic nephropathy, there is extensive mesangial expansion due to increased extracellular matrix production, with the formation of spherical, eosinophilic nodules with a central hypocellular or acellular area, known as Kimmelstiel-Wilson nodules (A) (hematoxylin-eosin, $\times 400)$. These nodules are also typically strongly periodic acid-Schiff-positive and may be seen compressing and narrowing the peripheral capillary loops (B) (periodic acid-Schiff, $\times 400$ ). The increased matrix stains dark with silver and the Kimmelstiel-Wilson nodules may demonstrate a lamellated appearance. Capillary microaneurysms can be seen at the periphery on the right (in the I-5 o'clock position), in association with mesangiolysis (C) (Masson's trichrome-methenamine silver, $\times 400$ ). There is diffuse thickening of the glomerular basement membrane, which is apparent on electron microscopy even if it is difficult to discern by light microscopy in early disease, and often accompanied by some degree of podocyte foot process effacement (D) (electron microscopy).

\section{Hemodynamic factors}

There is an imbalance in afferent and efferent arteriolar resistance, resulting in increased glomerular hydrostatic pressure and hyperfiltration. Activation of the renin-angiotensin system (RAS) increases angiotensin II levels, leading to efferent arteriolar vasoconstriction and production of proinflammatory and profibrotic molecules through multiple mechanisms. High angiotensin converting enzyme (ACE) levels are associated with greater albuminuria and nephropathy in diabetic mice and humans. ${ }^{34,35}$ Increased levels of endothelin- 1 and urotensin II also contribute to vasoconstriction. Various dysregulation of nitric oxide and nitric oxide synthase has been described in DN. Nitric oxide mediates endotheliumdependent vasodilatation, and is formed from L-arginine by endothelial nitric oxide synthase. Diabetic endothelial nitric oxide synthase knockout mice develop more severe glomerular lesions and proteinuria compared to wild-type mice. ${ }^{36}$

\section{Metabolic factors}

Oxidative stress and generation of reactive oxygen species (ROS) damage DNA and protein, or function as signaling amplifiers to activate cellular stress pathways such as PKC, MAPK, and NF- $\kappa B .{ }^{37,38}$ Activation of the polyol pathway, with aldose reductase converting excess glucose to sorbitol, and subsequent conversion to fructose by sorbitol dehydrogenase contributes to oxidative stress by increasing the NADH/ NAD+ ratio. ${ }^{39,40}$ A recently described novel mechanism of injury also involves endogenous fructose production with activation of fructokinase in the proximal tubule. ${ }^{41}$ The formation of advanced glycation end-products (AGE) by nonenzymatic binding of glucose to proteins, lipids, and nucleic acids can lead to alteration of protein structure and function, oxidative stress, and expression of proinflammatory cytokines and growth factors. ${ }^{42}$

\section{Growth factors/cytokines}

Activation of TGF- $\beta$ and its downstream cytokine, CTGF, induce extracellular matrix formation and fibrosis. In kidney biopsies, glomerular expression of TGF- $\beta 1$ and CTGF were higher in diabetics compared to controls, and correlated with albuminuria. PDGF expression is also increased in $\mathrm{DN}$, which can modulate chemotaxis, vascular tone, and 


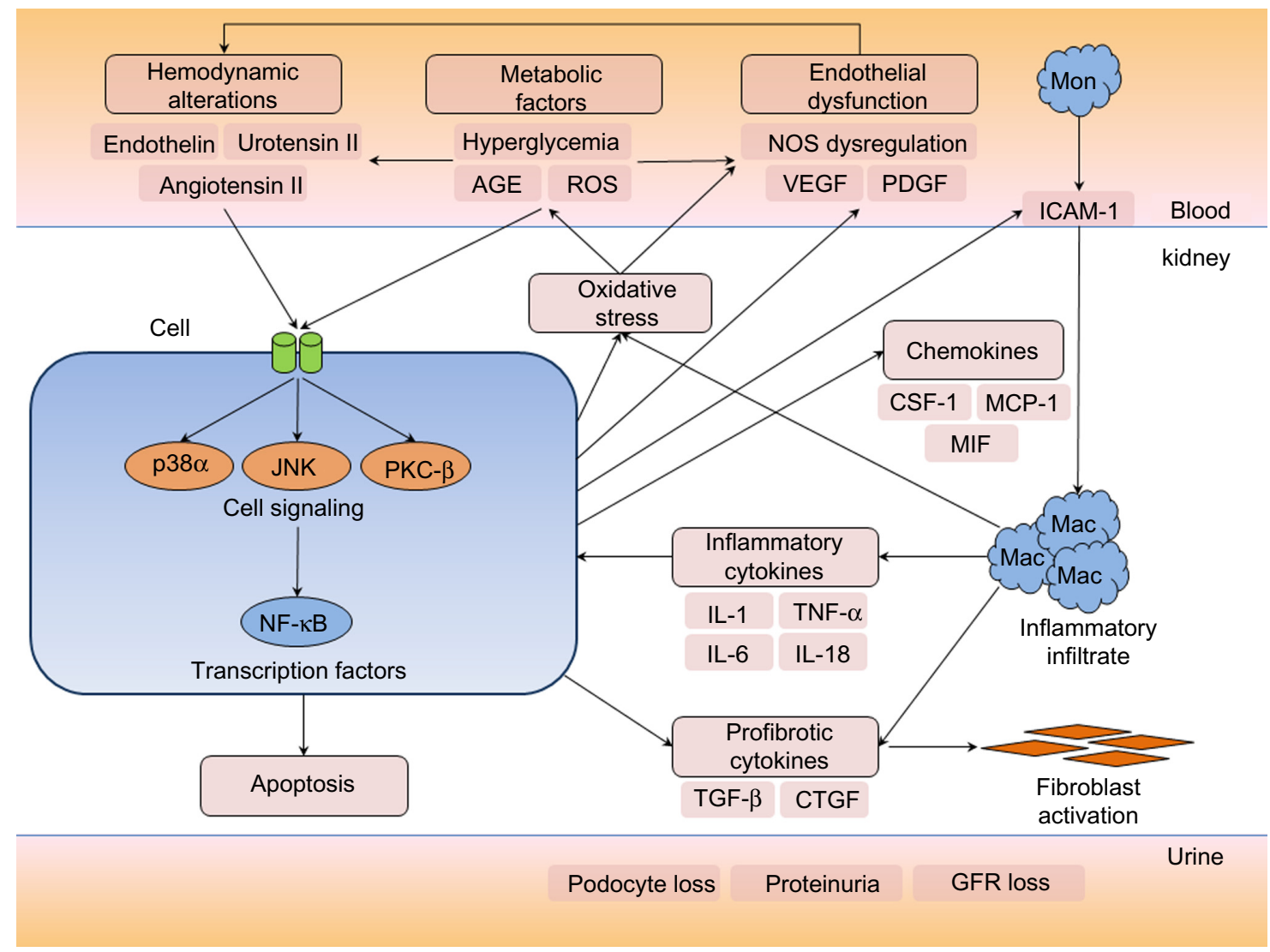

Figure 2 Overview of the pathological pathways in diabetic nephropathy.

Notes: In the diabetic milieu, metabolic derangements and hemodynamic alterations, particularly activation of the renin-angiotensin system, trigger a number of cell signaling cascades, including the MAPKs ( $\mathrm{p} 38$ and JNK) and PKC- $\beta$, which mediate a cellular response through activation of key transcription factors such as NF- $\mathrm{KB}$. In response to such signals, renal cells such as tubular epithelial cells, podocytes, and mesangial cells can produce chemokines, growth factors, and profibrotic cytokines. CSF-I and MCP-I function as chemotactic molecules and promote the recruitment of monocytes from the circulation. Upregulation of ICAM-I on endothelial cells - a key leukocyte adhesion molecule - facilitates infiltration of circulating mononuclear cells into the kidney. CSF-I also promotes monocyte/macrophage differentiation, proliferation, and activation. MIF functions to retain macrophages at sites of inflammation and has counter-regulatory functions against the anti-inflammatory actions of glucocorticoids. Activated macrophages can produce proinflammatory and profibrotic cytokines, reactive oxygen species, and antiangiogenic factors and contribute to a cycle of inflammation, oxidative stress, cellular injury, progressive fibrosis, and loss of glomerular filtration rate. Podocyte loss, endothelial dysfunction, alterations in the GBM, and tubular injury contribute to increasing proteinuria during the development and progression of diabetic nephropathy.

Abbreviations: AGE, advanced glycation end-products; GBM, glomerular basement membrane; GFR, glomerular filtration rate; Mac, macrophages; Mon, monocyte; NOS, nitric oxide synthase; ROS, reactive oxygen species.

platelet aggregation. VEGF is crucial in angiogenesis but also mediates vasodilatation and leukocyte trafficking in DN.

\section{Cell signaling and transcription factors}

Increased renal gene transcription of $\mathrm{PKC}-\beta$ showed a strong relationship with glycemic control. ${ }^{43} \mathrm{PKC}$ activation has wide ranging effects, including enhancing angiotensin II actions, nitric oxide dysregulation, endothelial dysfunction, and activation of MAPK and NF- $\kappa B .{ }^{44,45}$ MAPKs are intracellular kinases which integrate cell signaling into cellular responses. MAPKs activate a number of nuclear transcription factors, including $\mathrm{NF}-\kappa \mathrm{B}$, which then regulates the gene expression of various cytokines, chemokines, and adhesion molecules. The activation of $\mathrm{p} 38 \alpha$ isoform of the $\mathrm{p} 38$ MAPK pathway is most strongly associated with renal inflammation and DN. ${ }^{46,47}$ There may also be a role for toll-like receptors (TLR2, TLR4) and B7-1 costimulatory signaling in modulating inflammation and injury in DN. ${ }^{48,49}$ Finally, transcription factors bind to the promoter regions of genes and modulate transcription of messenger RNA. NF- $\mathrm{KB}$ has been the best studied in DN. Activation of NF- $\mathrm{BB}$ in both human peripheral blood mononuclear cells and kidney biopsies correlate with severity of proteinuria and glycemic control. ${ }^{50,51}$ A review of transcription factors in DN is provided by Sanchez and Sharma. ${ }^{52}$

\section{Inflammation}

In $\mathrm{DN}$, there is recruitment and activation of innate immune cells and elaboration of proinflammatory cytokines. ${ }^{53}$ Macrophages and T-lymphocytes are prominent in early diabetic glomeruli while an interstitial infiltrate develops later (Figure 3). Strategies impairing kidney leukocyte recruitment, proliferation, or activation have demonstrated 


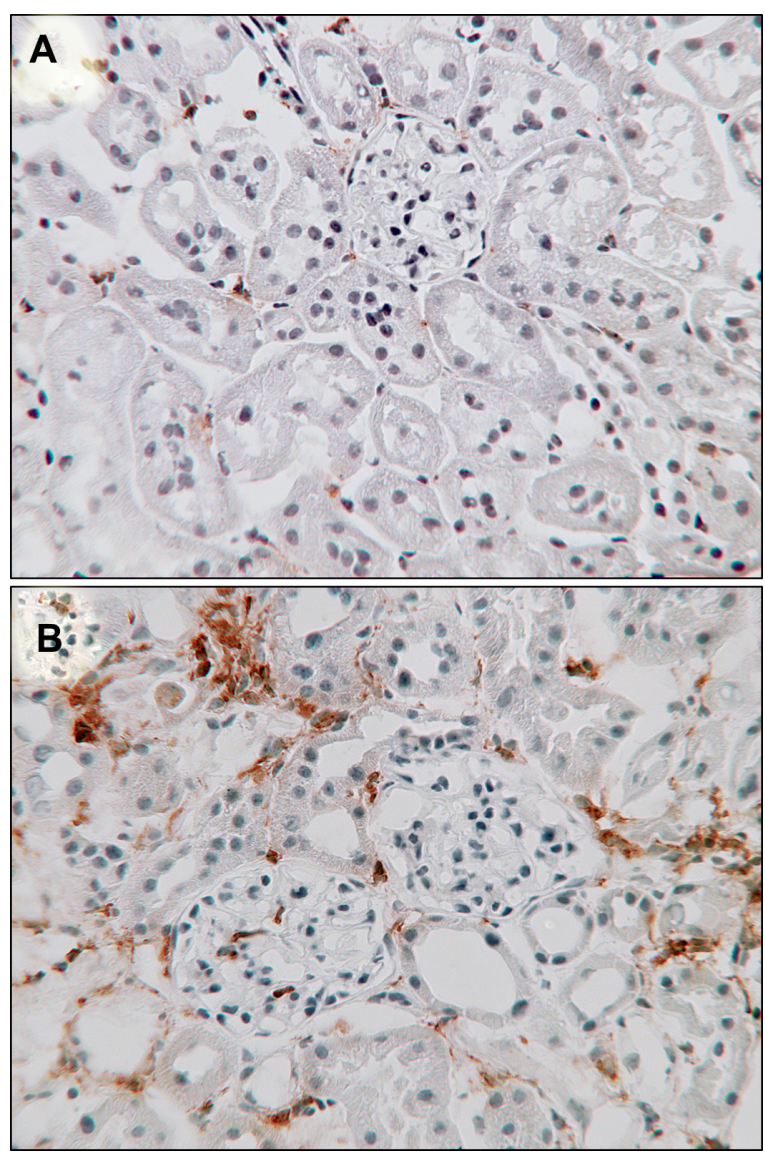

Figure 3 Macrophages in diabetic nephropathy.

Notes: Immunostaining for a macrophage marker (CD68) in kidney sections shows sparse interstitial macrophages in age-matched, nondiabetic control mice (A) compared to diabetic mice after 20 weeks of diabetes induced by streptozotocin (B) (CD68 brown, counterstained with hematoxylin, $\times 250$ ).

that macrophages mediate DN. ${ }^{54,55}$ In humans, kidney macrophage accumulation is associated with the severity of glomerulosclerosis. ${ }^{56}$ Accumulation of interstitial macrophages correlated strongly with proteinuria, interstitial fibrosis, and GFR decline. ${ }^{57}$

The role of lymphocytes is less clear. A higher circulating level of activated T-cells is associated with DN. ${ }^{58} \mathrm{~A}$ kidney T-cell influx is common in early type 1 diabetes, and correlates with renal function and albuminuria. ${ }^{59}$ However, absence of lymphocytes did not prevent fibrosis and declining renal function in experimental DN. ${ }^{60}$ Recent attention has focused on the subset of regulatory T-cells (Treg), which may play a protective role in DN. Treg numbers are increased in diabetic mice. ${ }^{60}$ Treg depletion in diabetic mice exacerbated albuminuria and hyperfiltration, while adoptive transfer of Treg improved DN. ${ }^{61}$ In type 2 diabetics, the number of Tregs as determined by flow cytometry showed an inverse correlation with albuminuria, particularly in patients with macroalbuminuria. ${ }^{62}$ Treg also demonstrated an anti-inflammatory function, which reduces the metabolic abnormalities and insulin resistance in a mouse model of type 2 diabetes. ${ }^{63}$ The main proinflammatory cytokines implicated in DN are TNF- $\alpha$, MCP-1, ICAM-1, IL-1, IL-6, and IL-18. These cytokines are increased in diabetic patients and show correlation with albuminuria and glomerular pathology. ${ }^{53}$

\section{Treatment}

Treatment to delay DN progression involves adequate control of metabolic and hemodynamic abnormalities. In practical terms, this means adequate blood glucose lowering and control of hypertension. A description of all glucose lowering agents is beyond the scope of this review but certain agents have theoretical benefits beyond glucose lowering. Certain antihypertensives are also preferred based on studies which have demonstrated reductions in proteinuria or preservation of GFR, or both. The main pharmacological interventions described here are summarized in Table 2. Nonpharmacological approaches and alternative medicine are briefly discussed. There is also interest in novel agents, gene therapy, and stem cell treatment, which may someday find a place in the treatment armamentarium.

\section{Glycemic control}

Good glycemic control is effective in reducing diabetic microvascular complications. DCCT was a trial involving

Table 2 Summary of pharmacological treatment of diabetic nephropathy

\begin{tabular}{|c|c|c|c|}
\hline Drug (s) & Antiproteinuric & $\begin{array}{l}\text { Preserve } \\
\text { GFR }\end{array}$ & $\begin{array}{l}\text { Diabetes } \\
\text { type }\end{array}$ \\
\hline ACE inhibitor & ++ & ++ & $\begin{array}{l}\text { Type I } \\
\text { and } 2\end{array}$ \\
\hline ARB & ++ & ++ & Type 2 \\
\hline ACE inhibitor plus ARB & +++ & - & $\begin{array}{l}\text { Type I } \\
\text { and } 2\end{array}$ \\
\hline Aldosterone antagonist & + & $?$ & Type 2 \\
\hline $\begin{array}{l}\text { Aldosterone antagonist } \\
\text { plus } A C E \text { inhibitor or } A R B\end{array}$ & +++ & $?$ & $\begin{array}{l}\text { Type I } \\
\text { and } 2\end{array}$ \\
\hline Renin inhibitor & ++ & $?$ & Type 2 \\
\hline $\begin{array}{l}\text { Renin inhibitor plus ACE } \\
\text { inhibitor or ARB }\end{array}$ & +++ & - & Type 2 \\
\hline Non-dihydropyridine CCB & + & ? & Type 2 \\
\hline $\begin{array}{l}\text { Non-dihydropyridine } C C B \\
\text { plus } A C E \text { inhibitor or } A R B\end{array}$ & ++ & $?$ & Type 2 \\
\hline Dihydropyridine CCB & - & - & Type 2 \\
\hline Allopurinol & $?$ & $?$ & $?$ \\
\hline Statin & + & $?$ & Type 2 \\
\hline Vitamin D & + & ? & Type 2 \\
\hline
\end{tabular}

Notes: + data exist to indicate benefit; - data exist to indicate lack of benefit or harm; ? insufficient data for conclusion, possible benefit. The number of + indicates a semiquantitative scale of beneficial effect.

Abbreviations: $A C E$, angiotensin converting enzyme; ARB, angiotensin receptor blocker; $C C B$, calcium channel blocker; GFR, glomerular filtration rate. 
1,365 type 1 diabetics and normoalbuminuria. After almost 10 years, patients randomized to intensive glucose control had lower incidences of microalbuminuria and macroalbuminuria. ${ }^{64}$ In the UKPDS trial of 3,867 newly diagnosed type 2 diabetics, patients receiving intensive glucose treatment were less likely to develop renal failure. ${ }^{65}$ In the ADVANCE trial of 11,140 type 2 diabetics, intensive therapy (mean hemoglobin $\mathrm{A}_{1 \mathrm{c}}\left[\mathrm{HbA}_{1 \mathrm{c}}\right] \leq 6.5 \%$ ) also reduced the incidence of nephropathy compared to standard control (mean $\mathrm{HbA}_{1 \mathrm{c}}$ 7.3\%). Intensive glucose control reduced the risk of ESRD by $65 \% .{ }^{66}$ In the VADT study of 1,791 type 2 diabetics, intensive glucose control (median $\mathrm{HbA}_{1 \mathrm{c}}$ 6.9\%) was associated with less worsening of albuminuria and progression to macroalbuminuria but no significant difference in GFR at 6 years. ${ }^{67}$ However, intensive glucose control to an $\mathrm{HbA}_{1 \mathrm{c}}$ of $<6 \%$ may confer excess mortality, as demonstrated in the ACCORD trial of type 2 diabetics with cardiovascular disease or cardiovascular risk factors. ${ }^{68,69}$ Thus, an $\mathrm{HbA}_{1 \mathrm{c}}$ of $<6 \%$, particularly if associated with significant hypoglycemic episodes, should be avoided.

Certain drugs may confer beneficial effects independent of glucose lowering. PPAR- $\gamma$ inhibitors such as pioglitazone and rosiglitazone have demonstrated antifibrotic and anti-inflammatory effects in the kidney of diabetic rats. ${ }^{70-72}$ In type 2 diabetics, the addition of rosiglitazone to metformin treatment for 32 weeks reduced albuminuria and blood pressure independent of glycemic control. ${ }^{73}$ DPP-4 inhibitors (gliptins) have shown anti-inflammatory and antiapoptotic properties in DN models. ${ }^{74}$ In type 2 diabetics, sitagliptin treatment for 6 months reduced albuminuria independent of $\mathrm{HbA}_{1 \mathrm{c}}{ }^{75}$ In a study of alogliptin in type 2 diabetics, researchers showed a reduction in oxidative stress but no change in renal function. ${ }^{76}$ Lastly, SGLT-2 inhibitors such as empagliflozin may reduce hyperfiltration by their effect on tubuloglomerular feedback. ${ }^{77}$ Further trial evidence is needed to determine if these agents should be preferred agents in patients with DN.

\section{Antihypertensives \\ ACE inhibitors}

ACE inhibitors have a strong track record in slowing disease progression in type 1 and type 2 diabetics. In the 1990s, captopril demonstrated the ability of ACE inhibitors in reducing the progression of albuminuria and decline in renal function in type 1 diabetics, independent of blood pressure lowering. ${ }^{78-80}$ In the Collaborative Study Group trial of 409 type 1 diabetics, captopril treatment reduced the risk of doubling of serum creatinine by $48 \%$ and reduced the composite outcome of death, dialysis, and transplantation by
$50 \%$ compared to placebo. ${ }^{80}$ This study also demonstrated that a sustained remission of nephrotic-range proteinuria was possible with ACE inhibitors. ${ }^{81}$ This was backed up by a study which showed that patients who achieved remission (albuminuria $<600 \mathrm{mg}$ /day) for $\geq 1$ year had better outcomes compared to those who did not, including slower decline in GFR and lower risk of dialysis, transplantation, or death. ${ }^{82,83}$

The perindopril/indapamide combination was studied in the ADVANCE trial of 11,140 type 2 diabetics. After mean follow-up of 4.3 years, perindopril/indapamide treatment reduced new onset microalbuminuria and prevented progression of microalbuminuria to overt nephropathy. However, serum creatinine and ESRD were not affected. It has also been argued that the effect on albuminuria was not independent of blood pressure, given a difference of 5.6/2.2 $\mathrm{mmHg}$ between the treatment groups.$^{84}$ Finally, the BENEDICT trial also showed that ACE inhibitor treatment could delay onset of microalbuminuria in type 2 diabetics with hypertension and baseline normoalbuminuria. ${ }^{85}$

\section{Angiotensin receptor blocker (ARB)}

In the IDNT trial, 1,715 hypertensive type 2 diabetics with nephropathy were randomly assigned to receive irbesartan, amlodipine, or placebo. ${ }^{86}$ Irbesartan reduced the risk of ESRD or doubling of serum creatinine by $20 \%-23 \%$ compared to amlodipine or placebo. In the RENAAL trial, 1,513 type 2 diabetics with nephropathy were randomly assigned to losartan or placebo, in addition to conventional antihypertensives. Losartan reduced the risk of ESRD or doubling of serum creatinine by $25 \%-28 \%$ compared to placebo. ${ }^{87}$ These effects were also independent of blood pressure lowering. Much like the early captopril studies in type 1 diabetics, a lower residual level of albuminuria was associated with lower ESRD risk. ${ }^{88}$ The ROADMAP trial of 4,447 type 2 diabetics randomized to olmesartan or placebo demonstrated that olmesartan was more effective in delaying the onset of microalbuminuria. However, the olmesartan group had a slightly lower blood pressure (mean difference 3.1/1.9 $\mathrm{mmHg}$ ) and there appeared to be a higher rate of fatal cardiovascular events in those with preexisting coronary artery disease. ${ }^{89}$

\section{$A C E$ inhibitor versus $A R B$}

In the DETAIL trial, 250 type 2 diabetics with early DN were randomly assigned to enalapril or telmisartan. This trial indicated that telmisartan was not inferior to enalapril in reducing a decline in GFR over 5 years. However, there was only a relatively small proportion of patients with overt nephropathy in this study. ${ }^{90}$ Given the paucity of data for 
ARBs in type 1 diabetics, some clinicians prefer initiating treatment with an ACE inhibitor for type $1 \mathrm{DN}$.

For primary prevention of $\mathrm{DN}$, a recent meta-analysis of eight studies and 11,906 participants found that ACE inhibitors reduced the risk of new onset microalbuminuria, macroalbuminuria, or both when compared to placebo (relative risk $0.71 ; 95 \%$ confidence interval $0.56-0.89$ ). However, similar benefits could not be demonstrated for ARBs. ${ }^{91}$ Thus, there is no proven benefit in starting ARB treatment in normotensive, normoalbuminuric type 1 or type 2 diabetics. Neither ACE inhibitor nor ARB is currently recommended in normotensive, normoalbuminuric diabetics for primary prevention of DN.

\section{ACE inhibitor and ARB}

Earlier studies of combination ACE inhibitor and ARB reported superiority of combination therapy for lowering albuminuria and blood pressure versus either alone, in both type 1 and 2 diabetics. ${ }^{92-94}$ One study also showed a reduction in urinary TGF- $\beta$ levels as another surrogate marker. ${ }^{95}$ Despite the positive effects on these surrogate markers, the impact on preservation of GFR has not been demonstrated. The ONTARGET trial, which combined ramipril and telmisartan in patients with DN, noted no significant difference in the incidence of dialysis or doubling of serum creatinine when compared to single RAS inhibition. ${ }^{96}$ In the Veterans Affairs NEPHRON-D study, the addition of lisinopril to losartan treatment did not reduce the composite endpoint of $50 \%$ reduction in eGFR, ESRD, or death. ${ }^{97}$ Furthermore, combination treatment was associated with higher incidences of acute kidney injury and hyperkalemia in both these trials. Thus, the dual ACE inhibitor/ARB treatment strategy for DN has largely been abandoned.

\section{Aldosterone antagonists}

Aldosterone is the final component of the RAS cascade. Aldosterone promotes fibrosis, inflammation, and generation of ROS, along with endothelial dysfunction, cell growth, and proliferation. ${ }^{98,99}$ Spironolactone appears to reduce proteinuria on its own or in combination with ACE inhibitor or $\mathrm{ARB}$, in both type 1 and type 2 diabetics. ${ }^{100,101}$ In addition to a blood pressure lowering effect, an anti-inflammatory mechanism is also likely, including reductions in MCP-1, MIF, and macrophage accumulation. ${ }^{102}$ In a randomized trial of 268 type 2 diabetics, the addition of eplerenone to an ACE inhibitor reduced albuminuria. ${ }^{103}$ However, the combination of aldosterone antagonists and other RAS inhibitors increases the risk of hyperkalemia and there is no long-term data on loss of renal function with combination blockade. Thus, combination of aldosterone antagonists and ACE inhibitor/ ARB is unclear but, if used, careful monitoring of blood potassium is recommended along with dietary limitation of potassium intake.

\section{Calcium channel blocker (CCB)}

The addition of a non-dihydropyridine CCB to RAS inhibition may also be beneficial. Both verapamil and diltiazem have been shown to lower proteinuria in type 2 diabetics. ${ }^{104}$ The effects of adding verapamil to lisinopril or trandolapril treatment were additive in reducing albuminuria and a decline in GFR. ${ }^{105,106}$ However, the BENEDICT-B study of verapamil in combination with trandolapril did not find an additional benefit in regression of macroalbuminuria in hypertensive type 2 diabetics independent of blood pressure lowering. ${ }^{107}$ In the MARVAL study of 332 type 2 diabetics randomized to valsartan or amlodipine (a dihydropyridine CCB) for 24 weeks, valsartan was more effective than amlodipine in reducing albuminuria, including remission to normoalbuminuria. ${ }^{108}$ Further evidence from the Nephros and REIN-2 studies in nondiabetic CKD suggests that dihydropyridine CCBs such as felodipine and amlodipine do not have additive value in reducing proteinuria or progression to ESRD when added to ramipril. ${ }^{109,110}$ Thus, the non-dihydropyridine CCBs may be considered second- or third-line agents after RAS inhibitors.

\section{Diuretics}

Similar to dietary sodium restriction, thiazide diuretics (eg, hydrochlorothiazide $50 \mathrm{mg}$ ) when combined with an ACE inhibitor (lisinopril $40 \mathrm{mg}$ /day) reduced albuminuria in type 2 diabetics. However, the combination is associated with more frequent orthostatic symptoms. ${ }^{82}$ For advanced $\mathrm{CKD}$, a loop diuretic may be more appropriate. Diuretics may increase the effectiveness of ACE inhibitors and ARBs.

\section{Blood pressure target}

The current Joint National Committee (JNC 8) guidelines recommend targeting a blood pressure of $<140 / 90 \mathrm{mmHg}$ for diabetic patients, irrespective of CKD. ${ }^{111}$ The 2013 European Society of Hypertension/European Society of Cardiology, ${ }^{112}$ 2014 Kidney Health Australia Caring for Australians with Renal Impairment, ${ }^{113}$ and 2012 Kidney Disease: Improving Global Outcomes guidelines advocate a similar target. However, a lower blood pressure target is recommended by some guidelines for better control of proteinuria. The 2014 Kidney Health Australia Caring for Australians with Renal 
Impairment guidelines recommend a lowering of the blood pressure target from $<140 / 90 \mathrm{mmHg}$ to $<130 / 80 \mathrm{mmHg}$ in the presence of macroalbuminuria. ${ }^{113}$ The 2012 Kidney Disease: Improving Global Outcomes guidelines suggest that a target of $<130 / 80$ would be more beneficial in those with micro- or macroalbuminuria. The National Kidney Foundation's (Kidney Disease Outcomes Quality Initiative) 2007 and 2012 updated guidelines advocate blood pressure readings $<130 / 80 \mathrm{mmHg}$ in diabetics with $\mathrm{CKD}$, or even lower in patients with high-level albuminuria (ACR $>500 \mathrm{mg} / \mathrm{g}) .{ }^{114}$ The Canadian Society of Nephrology continues to advocate for the lower target of $<130 / 80 \mathrm{mmHg}$ for all diabetics, regardless of CKD or albuminuria. ${ }^{115}$ It is probably sufficient to say that low risk diabetics with normoalbuminuria could be treated to a target of $<140 / 90 \mathrm{mmHg}$, while those at high risk or significant albuminuria should have a lower target of $<130 / 80 \mathrm{mmHg}$.

\section{Anti-lipid agents}

In the Casale Monferrato study of 1,253 type 2 diabetics, apolipoprotein B and high-density lipoprotein cholesterol levels were independent risk factors for progression to overt nephropathy during 7 years follow-up. ${ }^{19}$ In a large multinational case-control study of 2,535 type 2 diabetics with good control of low-density lipoprotein cholesterol, triglycerides and high-density lipoprotein cholesterol were associated with a higher risk of DN. ${ }^{116}$ Data from the Joslin Diabetes Center from 439 type 1 diabetics also indicated that elevated cholesterol levels $(>220 \mathrm{mg} / \mathrm{dL})$ was associated with progression of DN. ${ }^{117}$ Experimentally, statins have been shown to reduce NF- $\kappa \mathrm{B}$ activation by p38 MAPK in tubular cells, AGE-mediated ROS activation, and tubular apoptosis and suppress RAS activation and aldosterone production. ${ }^{118-120}$

Despite the epidemiological and experimental data, there is limited data from intervention studies with regards to renal outcomes. In a study of type 2 diabetics, simvastatin reduced albuminuria and improved expression of slit diaphragm proteins compared with cholestyramine despite similar lipid reductions. ${ }^{121}$ In an open-label randomized study in 104 type 2 diabetics, rosuvastatin reduced albuminuria and oxidative stress independent of lipid levels. ${ }^{122}$ The Heart Protection Study noted that simvastatin treatment was associated with a lesser decline in GFR compared to placebo after an average of 4.6 years, a difference which was bigger in diabetics compared to nondiabetics. ${ }^{123}$ The CARDS study of 2,838 type 2 diabetics randomized patients to atorvastatin or placebo, with a median follow-up of 3.9 years. Atorvastatin treatment improved the annual decline in eGFR, particularly in those with albuminuria. ${ }^{124}$ Currently, statins are already recommended for diabetics with DN over the age of 40 years, irrespective of their baseline lipid levels. This is primarily for cardiovascular benefit rather than renal disease per se, as albuminuria has been demonstrated to be an independent risk factor for cardiovascular events and mortality. ${ }^{125}$

\section{Uric acid}

Epidemiological studies demonstrate a strong link between uric acid and DN. The Joslin Diabetes Center study of 355 type 1 diabetics found that higher baseline uric acid levels was associated with early GFR loss over 4-6 years. ${ }^{126}$ Data from the Coronary Artery Calcification study, which included 324 type 1 diabetics with normoalbuminuria at baseline who were followed for 6 years, showed that for every $1 \mathrm{mg} / \mathrm{dL}$ increase in uric acid levels there was an $80 \%$ increased risk of developing micro- or macroalbuminuria. ${ }^{127}$ In the Steno Diabetes Center study of 263 type 1 diabetics, baseline serum uric acid at the onset of diabetes predicted development of macroalbuminuria 18 years later. ${ }^{128}$

Does lowering uric acid prevent progression of DN? A post hoc analysis of RENAAL noted that uric acid lowering by losartan may have accounted for $20 \%$ of the benefit afforded by the intervention. ${ }^{129}$ In diabetic mice, allopurinol attenuated albuminuria and tubulointerstitial injury, suggesting that uric acid is not just a potential marker but a therapeutic target. ${ }^{130,131}$ Allopurinol improves endothelial dysfunction and reduces urinary TGF- $\beta$ in DN. ${ }^{132-134}$ The PERL study is currently enrolling type 1 diabetics into a randomized trial of allopurinol versus placebo. ${ }^{135}$

\section{Vitamin D}

A low vitamin D level is common in patients with CKD. Vitamin D deficiency is linked to RAS activation and podocyte injury. ${ }^{136,137}$ Vitamin D may also play a role in preventing epithelial-to-mesenchymal transformation of tubular epithelial cells. ${ }^{138}$ Experimentally, active vitamin D also attenuated oxidative stress by restoring Nrf2 levels, important for cellular protection against oxidative injury. This was associated with reduced NF- $\kappa \mathrm{B}$ activation and lower albuminuria. ${ }^{139}$

Observational data from the PRONEDI trial of type 2 diabetics with stage $2-3$ CKD showed that vitamin D levels $<15 \mathrm{ng} / \mathrm{mL}$ was independently a risk factor for the composite outcome of $>50 \%$ increase in serum creatinine, ESRD, or death. ${ }^{140}$ In the VITAL study, type 2 diabetics randomized to paricalcitol (a synthetic $\mathrm{D}_{2}$ agonist) for 24 weeks achieved significantly lower albuminuria than 
placebo treatment. ${ }^{141}$ The upcoming VALIDATE-D study will evaluate the effect of calcitriol supplementation in patients on lisinopril to determine if there is a synergistic effect on RAS activity to lower proteinuria. ${ }^{142}$ Future randomized trials will hopefully determine the usefulness of targeting the vitamin $\mathrm{D}$ receptor in preserving GFR in DN.

\section{Lifestyle, diet, and alternative medicine}

Although moderate-intensity aerobic physical activity is recommended for all diabetics to improve glycemic control and cardiovascular risk, the DCCT study of type 1 diabetics found no evidence that physical activity prevents DN. ${ }^{143}$ Exercise may temporarily increase albumin excretion and should be avoided prior to urine collection for albumin excretion. On the other hand, the Look AHEAD study of type 2 diabetics suggested that intensive lifestyle intervention targeting weight loss may reduce progression of $\mathrm{CKD}$, despite no benefit on cardiovascular outcomes. ${ }^{144}$

A low protein diet is advocated by the American Diabetes Association. ${ }^{21}$ A recent meta-analysis of 13 randomized controlled trials with 779 type 1 and type 2 diabetics found that a low protein diet was associated with significant improvement in GFR. However, adequate compliance was necessary for this effect on GFR. Interestingly, proteinuria was not different between low protein and regular protein patients but $\mathrm{HbA}_{1 \mathrm{c}}$ decreased slightly with low protein intake
$(-0.26 \% ; 95 \%$ confidence interval -0.35 to -0.18$)$. Low protein intake was defined as $0.6-0.8 \mathrm{~g} / \mathrm{kg} /$ day and regular protein intake as $1.0-1.6 \mathrm{~g} / \mathrm{kg} /$ day. ${ }^{145}$

Substituting soy protein for animal protein may also be beneficial in diabetics with proteinuria but studies have not been consistent. ${ }^{146} \mathrm{~A}$ number of alternative medicine supplements have also been studied (Table 3). Lastly, sodium restriction to $50-70 \mathrm{mmol}$ daily may enhance the action of RAS inhibitors and result in a greater reduction in albuminuria in type 2 diabetics. ${ }^{147,148}$ However, this degree of sodium restriction is quite difficult for most and some advocate achieving an intake of $<100 \mathrm{mmol} /$ day as adequate restriction.

\section{Multifactorial risk factor reduction}

The benefits of intensive multifactorial intervention in type 2 diabetics were shown in the Steno-2 trial of 160 patients with microalbuminuria. Intensive therapy included: reduced dietary fat, light/moderate exercise, smoking cessation, tight glycemic control $(<6.5 \%)$, tight blood pressure control $(<130 / 80)$, ACE inhibitors, and anti-lipid medications (cholesterol $<4.5 \mathrm{mmol} / \mathrm{L}$ ). After a mean follow-up of 7.8 years, patients receiving multifactorial intervention had significantly lower risk of overt nephropathy (hazard ratio 0.39 ; $95 \%$ confidence interval $0.17-0.87$ ) than those receiving regular management. ${ }^{149}$

Table 3 Diet and alternative medicine

\begin{tabular}{|c|c|c|c|c|c|}
\hline Product & $\begin{array}{l}\text { Diabetes type } \\
\text { (patients, } \mathrm{n} \text { ) }\end{array}$ & Study design & Potential mechanisms & Key findings & Reference \\
\hline $\begin{array}{l}\text { Silymarin (milk } \\
\text { thistle, silybum) }\end{array}$ & Type 2 (60) & $\mathrm{RCT}$ & $\begin{array}{l}\text { Antioxidant, } \\
\text { anti-inflammatory } \\
\text { Antiapoptotic }\end{array}$ & $\begin{array}{l}\text { Silymarin ( } 140 \mathrm{mg} \text { three times daily) for } \\
3 \text { months reduced albuminuria, urine TNF- } \alpha \text {, } \\
\text { urine, and serum malondialdehyde (oxidative } \\
\text { stress marker) compared to baseline. }\end{array}$ & $\begin{array}{l}\text { Fallahzadeh } \\
\text { et } \mathrm{a}^{218}\end{array}$ \\
\hline \multirow[t]{2}{*}{ Zinc } & Type 2 (54) & Non-RCT & $\begin{array}{l}\text { Antioxidant, improved } \\
\text { glycemic control }\end{array}$ & $\begin{array}{l}\text { Zinc supplement ( } 50 \mathrm{mg} \text { elemental zinc) } \\
\text { for I } 2 \text { weeks improved glycemic control, } \\
\text { lipids, and albuminuria compared to baseline. } \\
\text { Effects on albuminuria were not shown to } \\
\text { be independent of other metabolic effects. }\end{array}$ & Khan et $\mathrm{al}^{219}$ \\
\hline & Type 2 (50) & RCT crossover & & $\begin{array}{l}\text { Zinc supplement ( } 30 \mathrm{mg} \text { elemental zinc) for } \\
\mathrm{I} 2 \text { weeks reduced } \mathrm{HbA}_{\mathrm{Ic}} \text { and albuminuria } \\
\text { compared to baseline. A 4-week washout } \\
\text { was carried out before crossover. }\end{array}$ & $\begin{array}{l}\text { Parham } \\
\text { et } \mathrm{al}^{220}\end{array}$ \\
\hline $\begin{array}{l}\text { Curcumin } \\
\text { (turmeric) }\end{array}$ & Type 2 (40) & $\mathrm{RCT}$ & Antioxidant & $\begin{array}{l}\text { Turmeric capsules } 500 \mathrm{mg} \text { three times daily } \\
\text { for } 2 \text { months reduced albuminuria, TGF- } \beta \text {, } \\
\text { and IL- I } 8 \text { levels compared to baseline. }\end{array}$ & $\begin{array}{l}\text { Khajehdehi } \\
\text { et } \mathrm{a}^{221}\end{array}$ \\
\hline Green tea & Recruiting & $\mathrm{RCT}$ & Antioxidant & $\begin{array}{l}\text { This trial is currently recruiting: Clinical Trials } \\
\text { NCTOI923597. Diabetic patients randomized } \\
\text { to green tea extract, epigallocatechin, } \\
\text { or placebo for } 3 \text { months. The primary } \\
\text { outcome is a change in albuminuria. }\end{array}$ & None \\
\hline Fish oil & Type I (36) & $\mathrm{RCT}$ & $\begin{array}{l}\text { Anti-inflammatory } \\
\text { Immunomodulatory }\end{array}$ & $\begin{array}{l}\text { I-year fish oil supplementation } 4.6 \mathrm{~g} / \text { day did } \\
\text { not affect albuminuria or kidney function. }\end{array}$ & $\begin{array}{l}\text { Rossing } \\
\text { et a }{ }^{222}\end{array}$ \\
\hline
\end{tabular}

Abbreviation: $\mathrm{HbA}_{\mathrm{lc}}$, hemoglobin $\mathrm{A}_{\mathrm{lc}} ; \mathrm{RCT}$, randomized controlled trial. 


\section{Transplantation}

Simultaneous pancreas/kidney transplantation is an effective treatment for type 1 diabetics with ESRD, with most achieving insulin independence and preventing recurrence of DN in the allograft. ${ }^{150,151}$ In patients with CKD after 10 years of pancreas transplantation alone, patients with sustained normoglycemia showed reductions in albuminuria and reversal of DN lesions on serial biopsy, including regression of glomerular basement membrane thickening and mesangial matrix deposition. ${ }^{152}$ Some of these benefits may be offset by interstitial fibrosis and arteriolar hyalinosis due to calcineurin inhibitor (eg, cyclosporine) use. However, the same authors note that tubulointerstitial remodeling at 10 years had ameliorated some of the interstitial collagen deposition noted at 5 years, although vascular changes were not affected. ${ }^{153}$

\section{Novel agents}

The diabetic milieu is a complex environment where a number of interventions may be utilized to target various pathological processes. As no single therapy completely ameliorates DN, novel strategies are needed to complement existing interventions. Some of these novel agents are described below and summarized in Table 4 .

\section{Renin inhibitors}

Renin catalyses the rate-limiting step in the production of angiotensin II. In diabetic rats, aliskiren reduced albu- minuria and glomerulosclerosis, and was more effective than perindopril in reducing interstitial fibrosis. ${ }^{154}$ In type 2 diabetics after a 4-week washout of previous medications, aliskiren reduced blood pressure and albuminuria, with the effects on albuminuria persisting after withdrawal of medication. ${ }^{155}$ In the AVOID trial of 599 type 2 diabetics, the combination of aliskiren $300 \mathrm{mg}$ and losartan $100 \mathrm{mg}$ for 6 months reduced the urine ACR independent of blood pressure. ${ }^{156}$ However, the much larger ALTITUDE trial, which randomized 8,561 high-risk type 2 diabetics to aliskiren $300 \mathrm{mg}$ or placebo as adjunctive to RAS inhibition, found no significant difference in renal outcomes. It is noted that the trial was terminated prematurely due to excess hyperkalemia and hypotension in the aliskiren group. ${ }^{157}$ Due to the lack of good randomized controlled trial evidence supporting the use of aliskiren in combination with $\mathrm{ACE}$ inhibitors or $\mathrm{ARBs}$, and the increased adverse effects, the combination is not recommended. From the US Food and Drug Administration perspective, the combination should be contraindicated in patients with diabetes. However, it could be considered as an alternative RAS blocker for blood pressure lowering and proteinuria reduction. More research is needed to demonstrate that aliskiren is as good as ACE inhibitors or ARBs.

\section{Endothelin inhibitors}

In diabetic rats, an $\mathrm{ET}_{\mathrm{A}}$ receptor blockade with atrasentan or avosentan reduced albuminuria and renal fibrosis. ${ }^{158,159}$

Table 4 Summary of novel agents

\begin{tabular}{|c|c|c|c|}
\hline Category & Mechanism of action & Drug(s) & Human data \\
\hline Direct renin inhibitors & Blocks conversion of angiotensinogen to angiotensin I. & Aliskiren & RCT \\
\hline \multirow[t]{2}{*}{ Endothelin inhibitors } & Predominantly blocks $\mathrm{ET}_{\mathrm{A}}$ receptors on vascular & Atrasentan & $\mathrm{RCT}$ \\
\hline & endothelium. & Avosentan & RCT \\
\hline Vasopeptidase & Blocks ACE and neutral endopeptidase. & Palosuran & RCT \\
\hline \multirow[t]{2}{*}{ inhibitors } & Palosuran blocks urotensin II receptor. & Omapatrilat & None \\
\hline & & llepatril & None \\
\hline PKC inhibitors & Blocks PKC- $\beta$ intracellular signaling. & Ruboxistaurin & RCT, pooled \\
\hline \multirow[t]{3}{*}{ Aldose reductase } & Reduces sorbitol formation by the polyol pathway. & Epalrestat & Non-RCT \\
\hline & & Ponalrestat & Non-RCT \\
\hline & & Tolrestat & None \\
\hline Phosphodiesterase & Increases cellular cAMP with broad effects. & Cilostazol & RCT \\
\hline inhibitors & $\begin{array}{l}\text { Cilostazol blocks PDE3, pentoxifylline is nonspecific } \\
\text { and also blocks the adenosine receptor. }\end{array}$ & Pentoxifylline & RCT, MetaAx \\
\hline \multirow[t]{3}{*}{ AGE inhibitors } & Blocks AGE formation, enhances breakdown, & Aminoguanidine & $\mathrm{RCT}$ \\
\hline & or breaks crosslinks. & Pyridoxamine & $\mathrm{RCT}$ \\
\hline & & Alegebrium & None \\
\hline Antioxidative stress & Activation of nuclear transcription factor Nrf2. & Bardoxolone & RCT \\
\hline Glycosaminoglycans & $\begin{array}{l}\text { Reduces heparan sulfate degradation in GBM, } \\
\text { anti-inflammatory actions. }\end{array}$ & Sulodexide & RCT \\
\hline Antifibrosis & $\begin{array}{l}\text { Reduces TGF- } \beta \text { signaling and TNF- } \alpha \text { levels } \\
\text { but exact mechanism unclear. }\end{array}$ & Pirfenidone & $\mathrm{RCT}$ \\
\hline
\end{tabular}

Abbreviations: AGE, advanced glycation end-products; cAMP, cyclic adenosine monophosphate; RCT, randomized controlled trial; MetaAx, meta-analysis; GBM, glomerular basement membrane. 
The ASCEND trial of 1,392 type 2 diabetics with overt nephropathy examined the effect of avosentan on time to doubling of serum creatinine, ESRD, or death. Avosentan halved proteinuria but increased fluid retention, edema, and congestive heart failure, resulting in the trial being stopped early. ${ }^{160}$ Since ASCEND, two other randomized controlled trials have noted reduction in albuminuria at the cost of edema and congestive heart failure. ${ }^{160,161}$ The latter trial involving 1,392 type 2 diabetics was also stopped prematurely after a median follow-up of 4 months. In a randomized trial of 211 type 2 diabetics, atrasentan added to RAS inhibition for 12 weeks reduced albuminuria in association with lowering blood pressure. ${ }^{162}$ Fluid overload was reported as manageable, albeit more patients discontinued treatment on the higher dose of atrasentan. The SONAR trial (NCT01858532) with atrasentan is currently in progress to evaluate renal outcomes in type 2 diabetics.

\section{Urotensin and vasopeptidase inhibitors}

Vasopeptidase inhibitors can block ACE and neutral endopeptidase. Palosuran is a competitive antagonist of the urotensin II receptor. In diabetic patients with macroalbuminuria, a 2-week course of palosuran in addition to RAS inhibitors reduced albuminuria by $24 \% .{ }^{163}$ The PROLONG trial is a prospective, randomized controlled crossover trial in hypertensive type 2 diabetics looking at the effects of palosuran on albuminuria and blood pressure. ${ }^{164}$ This study found no significant reduction in albuminuria or blood pressure after 4 weeks of treatment. Other vasopeptidase inhibitors such as omapatrilat and ilepatril (AVE7688) have been shown to attenuate albuminuria in diabetic rats but human data are lacking. ${ }^{165,166}$

\section{PKC inhibitors}

Ruboxistaurin is a selective inhibitor of PKC- $\beta$. Animal studies with ruboxistaurin showed beneficial effects on reducing mesangial expansion, hyperfiltration, albuminuria, macrophage accumulation, and tubulointerstitial injury. ${ }^{167,168}$ Small randomized controlled studies have demonstrated that ruboxistaurin reduced urinary TGF- $\beta$ excretion by $>50 \%,{ }^{169}$ reduced albuminuria, and preserved eGFR at 1 year in type 2 diabetics. ${ }^{170}$ However, when pooled data from three large studies of ruboxistaurin from diabetic retinopathy trials were analyzed $(n=1,157)$, ruboxistaurin was no different from placebo after 3 years in reducing the rates of doubling of serum creatinine or stage $4-5$ CKD. ${ }^{171}$

\section{Aldose reductase inhibitors}

These inhibitors suppress sorbitol accumulation in tissues. Epalrestat reduced mesangial expansion and preserved renal function in diabetic rats. ${ }^{172}$ Another inhibitor - tolrestat - prevented glomerular hypertrophy and hyperfiltration, mesangial cell hypocontractility, and albuminuria in diabetic rats. ${ }^{173} \mathrm{~A}$ small study of 35 type 2 diabetics showed that epalrestat treatment for 5 years prevented progression of microalbuminuria. ${ }^{174} \mathrm{~A}$ post hoc analysis of the Aldose Reductase Inhibitor-Diabetes Complications Trial concluded that progression of retinopathy/albuminuria was significantly inhibited by epalrestat. ${ }^{175}$ This was a re-analysis of the original 3-year, open-label trial using a subset of patients for which data were available. On the other hand, another inhibitor ponalrestat - did not affect urinary albumin excretion or glomerular filtration in type 1 diabetics. ${ }^{176}$

\section{Phosphodiesterase inhibitors}

Cilostazol inhibits phosphodiesterase III and reduces thrombospondin-1 and TGF- $\beta$ expression, attenuating hyperfiltration, albuminuria, and extracellular matrix deposition in diabetic rats. ${ }^{177,178}$ In humans, one study using cilostazol for 3 months in type 2 diabetics demonstrated a reduction in urinary ACR and renal production of thromboxane B2. ${ }^{179}$ A small Chinese study randomized 40 type 2 diabetics to cilostazol or placebo for 6 months. Cilostazol reduced albuminuria, serum ICAM-1, and MCP-1 levels but did not affect kidney function. ${ }^{180}$

Pentoxifylline is a methylxanthine-derived phosphodiesterase inhibitor that antagonizes the adenosine receptor and lowers blood viscosity. It also has anti-inflammatory and immunomodulatory properties, and lowers serum and urine TNF- $\alpha$ in diabetic patients with DN. In a Cochrane metaanalysis of 17 randomized trials involving 991 participants, pentoxifylline was better than placebo in reducing albuminuria and preserving serum creatinine but was equivalent to captopril. However, the studies were small and of poor methodology, with no data on ESRD or mortality. ${ }^{181}$ Since the meta-analysis, other trials have examined the addition of pentoxifylline to RAS blockers and have consistently found a benefit in reducing proteinuria. Roozbeh et al enrolled 74 patients with type 2 diabetes with overt proteinuria, randomized to pentoxifylline $400 \mathrm{mg}$ daily plus captopril or captopril alone. The reduction in proteinuria from baseline was greater in the pentoxifylline-treated group, associated with a modest reduction in blood pressure. ${ }^{182}$ Oliaei et al enrolled 50 type 2 diabetics with proteinuria $>500 \mathrm{mg} /$ day despite RAS inhibition, to pentoxifylline $400 \mathrm{mg}$ three times a day versus placebo. The pentoxifylline group had greater reductions in proteinuria but no difference in creatinine clearance. ${ }^{183}$ Ghorbani et al enrolled 100 type 2 diabetics 
with proteinuria randomized to pentoxifylline $400 \mathrm{mg}$ /day or placebo for 6 months. Both groups received losartan and enalapril in combination. After 6 months, pentoxifylline treatment was associated with lower proteinuria and higher creatinine clearance. ${ }^{184}$ The results of the PREDIAN study are still expected. ${ }^{185}$

\section{AGE inhibitors}

AGE inhibitors reduce AGE formation, enhance degradation, or break AGE crosslinks. The prototype AGE inhibitor is aminoguanidine (pimagedine), which acts by scavenging intermediates such as 3-deoxyglucosone and methyglyoxal. ${ }^{186}$ Experimentally, aminoguanidine attenuates albuminuria, mesangial expansion, and collagen deposition in diabetic rats. ${ }^{187}$ However, the placebo-controlled ACTION trial in 690 type 1 diabetics with overt nephropathy showed no difference in the time taken to double serum creatinine despite a reduction in proteinuria with pimagedine treatment for $2-4$ years. ${ }^{188}$

Pyridoxamine inhibits AGE formation and scavenges ROS and toxic carbonyls. When data from two 24-week studies were combined, pyridoxamine reduced the change from baseline creatinine in type 1 and type 2 diabetics without affecting albuminuria. ${ }^{189}$ However, in a randomized controlled trial of 317 type 2 diabetics, pyridoxamine treatment for 52 weeks did not significantly affect serum creatinine. ${ }^{190}$ GLY-230 is another inhibitor of protein glycation that was studied in 21 diabetic men in a randomized trial for 14 days. GLY-230 reduced glycated albumin and albuminuria compared to baseline but not placebo. ${ }^{191}$ AGE crosslink breakers, such as alegebrium, and inhibitors of the AGE receptor have shown benefit in DN models but have not been studied in humans.

\section{Agents targeting oxidative stress}

Cellular and mitochondrial ROS formation is an important contributor to the pathophysiology of DN. Targeted inhibitors of ROS generation are emerging but most have not progressed to clinical trials. Oxidative stress and inflammation in DN may also lead to a reduction in Nrf2, a nuclear transcription factor which plays a key role in antioxidant and cytoprotective mechanisms. ${ }^{192}$ Bardoxolone is a potent activator of Nrf2. In the BEAM trial of 227 type 2 diabetics with eGFR 20-45 $\mathrm{mL} / \mathrm{minute} / \mathrm{m}^{2}$ randomized to bardoxolone $(25,75$, or $150 \mathrm{mg}$ daily) or placebo, bardoxolone was associated with an improvement in eGFR at 24 weeks, which was sustained to 52 weeks of treatment. ${ }^{193}$ In the much larger BEACON trial of 2,185 type 2 diabetics with stage 4 CKD, patients were randomized to bardoxolone $20 \mathrm{mg}$ daily or placebo. The trial was stopped after a median follow-up of 9 months due to a higher rate of cardiovascular events and increased albuminuria, with no reduction in ESRD or cardiovascular death. ${ }^{194}$ Subsequently, one animal study in diabetic rats found unfavorable side effects of bardoxolone analogs, further questioning the safety profile in DN. ${ }^{195}$

\section{Glycosaminoglycans}

Sulodexide is a mixture of $80 \%$ heparan sulfate and $20 \%$ dermatan sulfate. Sulodexide may reduce the enhanced heparan sulfate degradation in the glomerular basement membrane that occurs in DN. It has anti-inflammatory properties and inhibits the hyperglycemia-induced production of ROS, MCP-1, and IL-6 in endothelial cells. ${ }^{196}$ It may improve endothelial dysfunction, vascular permeability, and renal hemodynamics. It may also attenuate TGF- $\beta$ gene expression, extracellular matrix expansion, and inhibit HPSE-1, which plays a role in tubular epithelial-to-mesenchymal transition. ${ }^{197}$

The DiNAS trial enrolled 223 type 1 and type 2 diabetics with serum creatinine $\leq 1.7 \mathrm{mg} / \mathrm{dL}$ in a randomized trial of sulodexide $(50,100,200 \mathrm{mg} /$ day $)$ versus placebo for 4 months, with a further 4 months follow-up postintervention. There was a dose-dependent effect, with $200 \mathrm{mg}$ /day the most effective in reducing albuminuria. RAS inhibition was not universal in this trial although post hoc analysis indicated the effect of sulodexide was additive to ACE inhibition. ${ }^{198}$ The Sun-MICRO trial enrolled 1,056 type 2 diabetics with microalbuminuria in a randomized trial of sulodexide $200 \mathrm{mg}$ /day versus placebo for 12 months. There was no difference between the groups in normalizing albumin excretion or reducing albuminuria by at least 50\%. ${ }^{199}$ The Sun-MACRO trial enrolled 1,248 type 2 diabetics with renal impairment and overt nephropathy in a randomized trial of sulodexide $200 \mathrm{mg} /$ day versus placebo. The study was terminated mid-enrollment, with data on 1,029 patient-years analyzed. This showed no significant difference in doubling of serum creatinine, ESRD, or creatinine $>6 \mathrm{mg} / \mathrm{dL} .{ }^{200}$ In both the SunMICRO and Sun-MACRO trials, patients were on maximum doses of RAS inhibitors. The latter studies have dampened the enthusiasm for sulodexide in DN.

\section{Antifibrotic agents}

Pirfenidone inhibits TGF- $\beta$ production and TNF- $\alpha$ production in models of DN and non-DN kidney disease. The exact mechanism of action is unclear. In $\mathrm{db} / \mathrm{db}$ mice with type 2 diabetes, pirfenidone reduced mesangial matrix expansion 
but did not affect albuminuria. ${ }^{201}$ In a small randomized trial of 77 type 1 and 2 diabetics with established DN, pirfenidone at 1,200 mg/day for 1 year improved eGFR from baseline compared to placebo (mean intergroup difference $5.5 \mathrm{~mL} / \mathrm{minute} / 1.73 \mathrm{~m}^{2}$ ). Pirfenidone at the higher dose of 2,400 mg/day did not demonstrate a similar benefit and the dropout rate was high. Pirfenidone did not lower albuminuria. Larger studies are needed to validate the findings.

\section{Gene and cell-based therapy}

Gene therapy involves introducing a gene into cells to increase the production of a protein of interest. A carrier or vector such as modified adenovirus is employed to deliver the gene to the nucleus where the protein coded by the gene is produced by the cellular machinery. Gene therapy targeting TGF- $\beta /$ SMAD signaling has shown promise in reducing kidney injury in diabetic models. Ka et al studied Smad7 gene therapy in the $\mathrm{db} / \mathrm{db}$ mouse model of type 2 diabetes. Treatment inhibited TGF- $\beta / \mathrm{SMAD}$ and NF- $\kappa \mathrm{B}$ activation, resulting in a reduction in proteinuria, macrophage infiltration, inflammation, podocyte injury, and renal fibrosis. ${ }^{202}$ A similar finding was noted by Zhang et al by using gene therapy to enhance decorin expression in the streptozotocin model of type 1 diabetes. The beneficial effects were attributed to downregulation of TGF- $\beta /$ SMAD signaling as decorin is a natural inhibitor of TGF- $\beta 1 .{ }^{203} \mathrm{HGF}$ gene therapy has been shown in $\mathrm{db} / \mathrm{db}$ mice to enhance renal expression of SDF-1, associated with increased numbers of bone marrow-derived monocyte/macrophages with a higher proportion of M2 markers (anti-inflammatory phenotype). This was associated with a reduction in proinflammatory cytokines, reduced histological injury, and preservation of podocytes. ${ }^{204}$ Kosugi et al examined soluble Flt-1 gene therapy in db/db mice. sFlt-1 is an endogenous inhibitor of VEGF and treated animals showed reduced VEGF expression in association with elevated sFlt-1 levels in the kidney. Although sFlt-1 gene therapy reduced podocyte injury and albuminuria, tubulointerstitial injury was enhanced, leading the authors to conclude that this approach would not be beneficial in DN. ${ }^{205}$ Thus, there are some potential risks with gene therapy, which may be related to the inserted gene itself or the viral vector utilized but this discussion is beyond the scope of this review.

Progenitor (stem) cells are multipotent cells capable of self-renewal and differentiation into specialized cells, and are broadly categorized into embryonic stem cells and adult stem cells. Adult stem cells can be derived from bone marrow, adipose tissue, or peripheral blood. Stem cells can also be harvested from umbilical cord blood at birth.

Table 5 Stem cell therapy in experimental diabetic nephropathy

\begin{tabular}{|c|c|c|c|}
\hline Source & Model & Main outcomes & Reference \\
\hline Human & TIDM, mice & $\downarrow$ glucose, $\uparrow$ insulin and $\beta$-cells, $\downarrow$ mesangial thickening, $\downarrow$ macrophage infiltration & Lee et $\mathrm{al}^{223}$ \\
\hline B-MSC & NOD/SCID & & \\
\hline Mouse & TIDM, mice & $\downarrow$ glucose, $\uparrow$ mouse insulin and $\beta$-cells, $\downarrow$ albuminuria, $\downarrow$ glomerular fibrosis & Ezquer et $\mathrm{al}^{224}$ \\
\hline B-MSC & C57BL/6 & and mesangial expansion & \\
\hline Mouse & TIDM, mice & No effect on glucose, insulin, or $\beta$-cells, $\downarrow$ albuminuria, $\downarrow$ glomerular fibrosis & Ezquer et $\mathrm{al}^{225}$ \\
\hline B-MSC & C57BL/6 & and mesangial expansion, $\downarrow$ podocyte loss & \\
\hline Rat & TIDM, rats & $\downarrow$ glucose, $\downarrow$ albuminuria, $\downarrow$ renal mass index & Zhou et $\mathrm{al}^{226}$ \\
\hline B-MSC & SD & & \\
\hline Human & TIDM, rats & No effect on glucose, $\downarrow$ proteinuria, $\downarrow$ fibronectin and $\alpha$-smooth muscle actin, & Park et al ${ }^{227}$ \\
\hline UC-MSC & SD & $\uparrow$ E-cadherin & \\
\hline Human & TIDM, rats & No effect on glucose, $\downarrow$ proteinuria, $\downarrow$ mesangial expansion, $\downarrow \alpha$-smooth muscle actin, & Park et a $\left.\right|^{228}$ \\
\hline UC-MSC & SD & TGF- $\beta$ I, and collagen, $\uparrow$ E-cadherin & \\
\hline Rat & TIDM, rats & $\downarrow$ glucose, $\uparrow$ insulin, $\downarrow$ lipids, $\downarrow$ creatinine, $\downarrow$ mesangial expansion, $\downarrow$ oxidative stress, & Fang et $\mathrm{al}^{229}$ \\
\hline A-MSC & SD & $\downarrow$ proinflammatory cytokines (TNF- $\alpha$, IL-I $\beta$, IL-6), $\downarrow$ MAPK signaling (P38, ERK, JNK) & \\
\hline Rat & TIDM, rats & No effect on glucose, $\downarrow$ albuminuria, $\downarrow$ BMP- $7, \downarrow$ podocyte injury and loss, & Wang et $\mathrm{al}^{230}$ \\
\hline B-MSC & SD & $\uparrow$ creatinine clearance, $\downarrow$ renal mass index & \\
\hline Rat & TIDM, rats & $\downarrow$ glucose and albuminuria, $\downarrow$ glomerulosclerosis, $\downarrow$ MCP-I and macrophages, & Lv et $\mathrm{al}^{231}$ \\
\hline B-MSC & Wistar & $\uparrow$ HGF, $\downarrow$ proinflammatory cytokines (IL-I $\beta$, IL-6, TNF- $\alpha$ ) & \\
\hline Rat & TIDM, rats & $\downarrow$ glucose, $\uparrow$ insulin and $\beta$-cells, $\downarrow$ albuminuria, $\uparrow$ synaptopodin, $\downarrow$ TGF- $\beta$ I, $\uparrow$ IL-I0 & Zhang et $\mathrm{al}^{232}$ \\
\hline B-MSC & SD & & \\
\hline Human & TIDM, rats & No effect on glucose or $\beta$ cells, $\downarrow$ proteinuria, $\uparrow$ creatinine clearance, $\downarrow$ cholesterol, & Zhang et $\mathrm{al}^{233}$ \\
\hline A-MSC & SD & $\downarrow$ glomerular hypertrophy, $\downarrow$ podocyte injury/loss, $\downarrow$ interstitial fibrosis & \\
\hline Rat & TIDM, rats & $\downarrow$ urea and creatinine, $\downarrow$ albuminuria, $\downarrow$ Bax expression, $\downarrow$ TGF- $\beta$ and TNF- $\alpha, \uparrow$ VEGF & Abdel Aziz et $\mathrm{al}^{234}$ \\
\hline B-MSC & Albino & & \\
\hline
\end{tabular}

Note: a down arrow indicates a reduction or decrease; an up arrow indicates an increase.

Abbreviations: A-MSC, adipose-derived mesenchymal stromal (stem) cells; B-MSC, bone marrow-derived mesenchymal stromal (stem) cells; SD, Sprague Dawley; TIDM, streptozotocin-induced model of type I diabetes; UC-MSC, umbilical cord blood-derived mesenchymal stromal (stem) cells. 
The potential benefits of stem cell treatment in DN include: 1) replacing or regenerating damaged cells, 2) modulating inflammation, 3) reducing oxidative stress, and 4) improving glycemia. There have been a number of experimental studies of stem cell treatment in DN (Table 5). Most studies have demonstrated a blood glucose lowering effect by improved pancreatic $\beta$-cell function and insulin levels, whilst some others have not. This may relate to the nature of the cells utilized or the method of delivery. Some of these studies suggest that a paracrine effect is more important as a renoprotective mechanism, rather than regeneration or replacement of injured cells. This is based on observations of low level engraftment of mesenchymal stem cells in the kidney and the production of beneficial growth factors, antifibrotic factors, and factors which protect from oxidative stress. ${ }^{206,207}$

The main issues facing cell-based therapy include: 1) consistency of manufactured cells (phenotypic change occur with repeat passages), 2) cell delivery method (optimize tissue targeting and minimizing passive entrapment), and 3 ) engrafting and cell survival. Notwithstanding the limitations mentioned, both gene therapy and stem cell therapy are promising areas of research but there are currently no successful human studies to date. Further studies are also needed to confirm that mesenchymal stem cells ameliorate $\mathrm{DN}$ independent of its metabolic benefits.

\section{Conclusion}

$\mathrm{DN}$ and ESRD remains a significant problem despite best efforts to limit the impact of the disease on such end-organ damage. In such a complex milieu of diabetes where no single treatment can halt DN progression, a multifactorial approach remains the most sensible. This should include optimal glycemic control and single RAS inhibition for hypertension or albuminuria. Based on the evidence, ACE inhibitors are preferred for type 1 diabetics. Second-line antihypertensives include non-dihydropyridine CCBs and diuretics. Lipid management with a statin is prudent for cardiovascular disease even though a direct impact on renal disease has not been conclusively shown other than as part of the multifactorial risk intervention similar to the Steno-2 study (which includes aspirin). No alternative medicines or supplements have been shown to slow GFR decline although effects on albuminuria are reported by some small studies. None can be routinely recommended currently and further studies on vitamin D are awaited. Further data on uric acid management with allopurinol are also awaited. Mild salt and protein restriction may also benefit some patients but strict monitoring and compliance can be problematic.
Understanding the pathophysiology of DN has improved over the years, particularly the molecular biology aspect. Inflammation has emerged as an important theme, while treatment targets and options continue to evolve as knowledge improves. The inflammatory amplification loop mediated by macrophages may be a good candidate for inhibition to reduce DN progression. Leukocyte or monocyte/macrophage culling may not necessarily be the best long-term strategy but manipulation of the macrophage phenotype and the interaction with T-cells should be further investigated. Blocking specific cell signaling pathways involved with inflammation may be useful but can be troubled by off-target effects, which will need to be fully explored before clinical trials can proceed.

A number of potential treatment strategies have shown benefit in improving surrogate markers like albuminuria but the translation to preserving GFR and preventing ESRD has not always followed. Such is the case with dual or triple blockade of the RAS system in DN seen in recent large clinical trials. It is acknowledged that albuminuria as a surrogate marker of disease progression is flawed. Furthermore, experimental interventions which reduce histological injury and inflammation do not always reduce the level of established proteinuria. Novel biomarkers may assist in this area when more data becomes available. Despite these challenges, new strategies to complement existing treatments will nonetheless continue to be looked for.

\section{Acknowledgments}

The author thanks Dr Ian Simpson (Renal Pathologist, Department of Anatomical Pathology, Monash Health) for his contribution of the histology images and pathology descriptions. The author also thanks Mr Paul Crammer (Renal Scientist, Department of Anatomical Pathology, Monash Health) for the electron microscopy image.

\section{Disclosure}

The author reports no conflicts of interest in this work. This manuscript has not been submitted or published anywhere else.

\section{References}

1. International Diabetes Federation. IDF Diabetes Atlas. 6th ed. Brussels, Belgium: International Diabetes Federation; 2013. Available from: http:// www.idf.org/sites/default/files/EN_6E_Atlas_Full_0.pdf. Accessed September 2, 2014.

2. Centers for Disease Control and Prevention. National diabetes fact sheet national estimates and general information on diabetes and prediabetes in the United States. Atlanta, GA: US Department of Health and Human Services; 2011. Available from: http://www.cdc.gov/diabetes/pubs/pdf/ ndfs_2011.pdf. Accessed September 2, 2014. 
3. Tapp RJ, Shaw JE, Zimmet PZ, et al. Albuminuria is evident in the early stages of diabetes onset: results from the Australian Diabetes, Obesity, and Lifestyle Study (AusDiab). Am J Kidney Dis. 2004;44(5): 792-798.

4. Scott LJ, Warram JH, Hanna LS, Laffel LM, Ryan L, Krolewski AS. A nonlinear effect of hyperglycemia and current cigarette smoking are major determinants of the onset of microalbuminuria in type 1 diabetes. Diabetes. 2001;50(12):2842-2849.

5. Rossing P, Hougaard P, Parving HH. Risk factors for development of incipient and overt diabetic nephropathy in type 1 diabetic patients: a 10-year prospective observational study. Diabetes Care. 2002;25(5): 859-864.

6. Satko SG, Langefeld CD, Daeihagh P, Bowden DW, Rich SS, Freedman BI. Nephropathy in siblings of African Americans with overt type 2 diabetic nephropathy. Am J Kidney Dis. 2002;40(3):489-494.

7. Pettitt DJ, Saad MF, Bennett PH, Nelson RG, Knowler WC. Familial predisposition to renal disease in two generations of Pima Indians with type 2 (non-insulin-dependent) diabetes mellitus. Diabetologia. 1990;33(7):438-443.

8. Seaquist ER, Goetz FC, Rich S, Barbosa J. Familial clustering of diabetic kidney disease. Evidence for genetic susceptibility to diabetic nephropathy. N Engl J Med. 1989;320(18):1161-1165.

9. Young BA, Maynard C, Boyko EJ. Racial differences in diabetic nephropathy, cardiovascular disease, and mortality in a national population of veterans. Diabetes Care. 2003;26(8):2392-2399.

10. Smith SR, Svetkey LP, Dennis VW. Racial differences in the incidence and progression of renal diseases. Kidney Int. 1991;40(5): 815-822.

11. Gall MA, Hougaard P, Borch-Johnsen K, Parving HH. Risk factors for development of incipient and overt diabetic nephropathy in patients with non-insulin dependent diabetes mellitus: prospective, observational study. BMJ. 1997;314(7083):783-788.

12. Mooyaart AL, Valk EJ, van Es LA, et al. Genetic associations in diabetic nephropathy: a meta-analysis. Diabetologia. 2011;54(3):544-553.

13. Dellamea BS, Pinto LC, Leitao CB, Santos KG, Canani LH. Endothelial nitric oxide synthase gene polymorphisms and risk of diabetic nephropathy: a systematic review and meta-analysis. BMC Med Genet. 2014;15:9.

14. Lin Z, Huang G, Zhang J, Lin X. Adiponectin gene polymorphisms and susceptibility to diabetic nephropathy: a meta-analysis. Ren Fail. 2014;36(3):478-487.

15. Zhou TB, Guo XF, Yin SS. Association of peroxisome proliferatoractivated receptor $\gamma$ Pro12Ala gene polymorphism with type 2 diabetic nephropathy risk in Caucasian population. J Recept Signal Transduct Res. 2014;34(3):180-184.

16. Mooyaart AL. Genetic associations in diabetic nephropathy. Clin Exp Nephrol. 2014;18(2):197-200.

17. Molitch ME, DeFronzo RA, Franz MJ, et al; American Diabetes Association. Nephropathy in diabetes. Diabetes Care. 2004; 27(Suppl 1):S79-S83.

18. Drummond K, Mauer M. The early natural history of nephropathy in type 1 diabetes: II. Early renal structural changes in type 1 diabetes. Diabetes. 2002;51(5):1580-1587.

19. Bruno G, Merletti F, Biggeri A, et al. Progression to overt nephropathy in type 2 diabetes: the Casale Monferrato Study. Diabetes Care. 2003;26(7):2150-2155.

20. Johnson DW, Jones GR, Mathew TH, et al. Chronic kidney disease and measurement of albuminuria or proteinuria: a position statement. Med J Aust. 2012;197(4):224-225.

21. American Diabetes Association. Standards of Medical Care in Diabetes 2014. Diabetes Care. 2014;37(Supp1 1):S14-S80.

22. Mazzucco G, Bertani T, Fortunato M, et al. Different patterns of renal damage in type 2 diabetes mellitus: a multicentric study on 393 biopsies. Am J Kidney Dis. 2002;39(4):713-720.

23. Mak SK, Gwi E, Chan KW, et al. Clinical predictors of non-diabetic renal disease in patients with non-insulin dependent diabetes mellitus. Nephrol Dial Transplant. 1997;12(12):2588-2591.
24. Sharma SG, Bomback AS, Radhakrishnan J, et al. The modern spectrum of renal biopsy findings in patients with diabetes. Clin J Am Soc Nephrol. 2013;8(10):1718-1724.

25. Perkins BA, Ficociello LH, Roshan B, Warram JH, Krolewski AS. In patients with type 1 diabetes and new-onset microalbuminuria the development of advanced chronic kidney disease may not require progression to proteinuria. Kidney Int. 2010;77(1):57-64.

26. Caramori ML, Fioretto P, Mauer M. Low glomerular filtration rate in normoalbuminuric type 1 diabetic patients: an indicator of more advanced glomerular lesions. Diabetes. 2003;52(4):1036-1040.

27. Perkins BA, Ficociello LH, Ostrander BE, et al. Microalbuminuria and the risk for early progressive renal function decline in type 1 diabetes. J Am Soc Nephrol. 2007;18(4):1353-1361.

28. Argyropoulos C, Wang K, McClarty S, et al. Urinary microRNA profiling in the nephropathy of type 1 diabetes. PLoS One. 2013;8(1):e54662.

29. DiStefano JK, Taila M, Alvarez ML. Emerging roles for miRNAs in the development, diagnosis, and treatment of diabetic nephropathy. Curr Diab Rep. 2013;13(4):582-591.

30. Gohda T, Niewczas MA, Ficociello LH, et al. Circulating TNF receptors 1 and 2 predict stage $3 \mathrm{CKD}$ in type 1 diabetes. J Am Soc Nephrol. 2012;23(3):516-524.

31. Niewczas MA, Gohda T, Skupien J, et al. Circulating TNF receptors 1 and 2 predict ESRD in type 2 diabetes. J Am Soc Nephrol. 2012;23(3): 507-515.

32. Weil EJ, Lemley KV, Mason CC, et al. Podocyte detachment and reduced glomerular capillary endothelial fenestration promote kidney disease in type 2 diabetic nephropathy. Kidney Int. 2012;82(9):1010-1017.

33. Toyoda M, Najafian B, Kim Y, Caramori ML, Mauer M. Podocyte detachment and reduced glomerular capillary endothelial fenestration in human type 1 diabetic nephropathy. Diabetes. 2007;56(8):2155-2160.

34. Huang W, Gallois Y, Bouby N, et al. Genetically increased angiotensin I-converting enzyme level and renal complications in the diabetic mouse. Proc Natl Acad Sci U S A. 2001;98(23):13330-13334.

35. Rudberg S, Rasmussen LM, Bangstad HJ, Osterby R. Influence of insertion/deletion polymorphism in the ACE-I gene on the progression of diabetic glomerulopathy in type 1 diabetic patients with microalbuminuria. Diabetes Care. 2000;23(4):544-548.

36. Kanetsuna Y, Takahashi K, Nagata M, et al. Deficiency of endothelial nitric-oxide synthase confers susceptibility to diabetic nephropathy in nephropathy-resistant inbred mice. Am J Pathol. 2007;170(5): 1473-1484.

37. Haneda M, Araki S, Togawa M, Sugimoto T, Isono M, Kikkawa R. Mitogen-activated protein kinase cascade is activated in glomeruli of diabetic rats and glomerular mesangial cells cultured under high glucose conditions. Diabetes. 1997;46(5):847-853.

38. Ha H, Lee HB. Reactive oxygen species as glucose signaling molecules in mesangial cells cultured under high glucose. Kidney Int Suppl. 2000;77:S19-S25.

39. Srivastava SK, Ramana KV, Bhatnagar A. Role of aldose reductase and oxidative damage in diabetes and the consequent potential for therapeutic options. Endocr Rev. 2005;26(3):380-392.

40. Williamson JR, Chang K, Frangos M, et al. Hyperglycemic pseudohypoxia and diabetic complications. Diabetes. 1993;42(6):801-813.

41. Lanaspa MA, Ishimoto T, Cicerchi C, et al. Endogenous fructose production and fructokinase activation mediate renal injury in diabetic nephropathy. J Am Soc Nephrol. Epub May 29, 2014.

42. Sheetz MJ, King GL. Molecular understanding of hyperglycemia's adverse effects for diabetic complications. JAMA. 2002;288(20): 2579-2588.

43. Langham RG, Kelly DJ, Gow RM, et al. Increased renal gene transcription of protein kinase C-beta in human diabetic nephropathy: relationship to long-term glycaemic control. Diabetologia. 2008;51(4):668-674.

44. Noh H, King GL. The role of protein kinase $\mathrm{C}$ activation in diabetic nephropathy. Kidney Int Suppl. 2007;(106):S49-S53.

45. Derubertis FR, Craven PA. Activation of protein kinase $\mathrm{C}$ in glomerular cells in diabetes. Mechanisms and potential links to the pathogenesis of diabetic glomerulopathy. Diabetes. 1994;43(1):1-8. 
46. Sakai N, Wada T, Furuichi K, et al. Involvement of extracellular signalregulated kinase and p38 in human diabetic nephropathy. Am J Kidney Dis. 2005;45(1):54-65.

47. Adhikary L, Chow F, Nikolic-Paterson DJ, et al. Abnormal p38 mitogenactivated protein kinase signalling in human and experimental diabetic nephropathy. Diabetologia. 2004;47(7):1210-1222.

48. Fiorina P, Vergani A, Bassi R, et al. Role of podocyte B7-1 in diabetic nephropathy. J Am Soc Nephrol. 2014;25(7):1415-1429.

49. Mudaliar H, Pollock C, Komala MG, Chadban S, Wu H, Panchapakesan U. The role of Toll-like receptor proteins (TLR) 2 and 4 in mediating inflammation in proximal tubules. Am J Physiol Renal Physiol. 2013;305(2):F143-F154.

50. Schmid H, Boucherot A, Yasuda Y, et al. Modular activation of nuclear factor-kappaB transcriptional programs in human diabetic nephropathy. Diabetes. 2006;55(11):2993-3003.

51. Hofmann MA, Schiekofer S, Kanitz M, et al. Insufficient glycemic control increases nuclear factor-kappa B binding activity in peripheral blood mononuclear cells isolated from patients with type 1 diabetes. Diabetes Care. 1998;21(8):1310-1316.

52. Sanchez AP, Sharma K. Transcription factors in the pathogenesis of diabetic nephropathy. Expert Rev Mol Med. 2009;11:e13.

53. Lim AK, Tesch GH. Inflammation in diabetic nephropathy. Mediators Inflamm. 2012;2012:146154.

54. Chow FY, Nikolic-Paterson DJ, Ma FY, Ozols E, Rollins BJ, Tesch GH. Monocyte chemoattractant protein-1-induced tissue inflammation is critical for the development of renal injury but not type 2 diabetes in obese db/db mice. Diabetologia. 2007;50(2):471-480.

55. Lim AK, Ma FY, Nikolic-Paterson DJ, Thomas MC, Hurst LA, Tesch GH. Antibody blockade of c-fms suppresses the progression of inflammation and injury in early diabetic nephropathy in obese $\mathrm{db} / \mathrm{db}$ mice. Diabetologia. 2009;52(8):1669-1679.

56. Furuta T, Saito T, Ootaka T, et al. The role of macrophages in diabetic glomerulosclerosis. Am J Kidney Dis. 1993;21(5):480-485.

57. Nguyen D, Ping F, Mu W, Hill P, Atkins RC, Chadban SJ. Macrophage accumulation in human progressive diabetic nephropathy. Nephrology (Carlton). 2006;11(3):226-231.

58. Bending JJ, Lobo-Yeo A, Vergani D, Viberti GC. Proteinuria and activated T-lymphocytes in diabetic nephropathy. Diabetes. 1988;37(5):507-511.

59. Moriya R, Manivel JC, Mauer M. Juxtaglomerular apparatus T-cell infiltration affects glomerular structure in Type 1 diabetic patients. Diabetologia. 2004;47(1):82-88.

60. Lim AK, Ma FY, Nikolic-Paterson DJ, Kitching AR, Thomas MC, Tesch GH. Lymphocytes promote albuminuria, but not renal dysfunction or histological damage in a mouse model of diabetic renal injury. Diabetologia. 2010;53(8):1772-1782.

61. Eller K, Kirsch A, Wolf AM, et al. Potential role of regulatory T cells in reversing obesity-linked insulin resistance and diabetic nephropathy. Diabetes. 2011;60(11):2954-2962.

62. Xu J, Su HL, Wang JH, Zhang CH. [Role of CD4+CD25+Foxp3+ regulatory T cells in type 2 diabetic nephropathy]. Nan Fang Yi Ke Da Xие Xие Bao. 2009;29(1):137-139. Chinese.

63. Ilan Y, Maron R, Tukpah AM, et al. Induction of regulatory $\mathrm{T}$ cells decreases adipose inflammation and alleviates insulin resistance in ob/ob mice. Proc Natl Acad Sci U S A. 2010;107(21):9765-9770.

64. The Diabetes Control and Complications Trial Research Group. The effect of intensive treatment of diabetes on the development and progression of long-term complications in insulin-dependent diabetes mellitus. N Engl J Med. 1993;329(14):977-986.

65. Holman RR, Paul SK, Bethel MA, Matthews DR, Neil HA. 10-year follow-up of intensive glucose control in type 2 diabetes. $N$ Engl J Med. 2008;359(15):1577-1589.

66. Perkovic V, Heerspink HL, Chalmers J, et al. Intensive glucose control improves kidney outcomes in patients with type 2 diabetes. Kidney Int. 2013;83(3):517-523

67. Duckworth W, Abraira C, Moritz T, et al. Glucose control and vascular complications in veterans with type 2 diabetes. $N$ Engl J Med. 2009;360(2):129-139.
68. Gerstein HC, Miller ME, Byington RP, et al. Effects of intensive glucose lowering in type 2 diabetes. $N$ Engl J Med. 2008;358(24):2545-2559.

69. Ismail-Beigi F, Craven T, Banerji MA, et al. Effect of intensive treatment of hyperglycaemia on microvascular outcomes in type 2 diabetes: an analysis of the ACCORD randomised trial. Lancet. 2010;376(9739): 419-430.

70. Ko GJ, Kang YS, Han SY, et al. Pioglitazone attenuates diabetic nephropathy through an anti-inflammatory mechanism in type 2 diabetic rats. Nephrol Dial Transplant. 2008;23(9):2750-2760.

71. Ohga S, Shikata K, Yozai K, et al. Thiazolidinedione ameliorates renal injury in experimental diabetic rats through anti-inflammatory effects mediated by inhibition of NF-kappaB activation. Am J Physiol Renal Physiol. 2007;292(4):F1141-F1150.

72. Zhang H, Saha J, Byun J, et al. Rosiglitazone reduces renal and plasma markers of oxidative injury and reverses urinary metabolite abnormalities in the amelioration of diabetic nephropathy. Am J Physiol Renal Physiol. 2008;295(4):F1071-F1081.

73. Bakris GL, Ruilope LM, McMorn SO, et al. Rosiglitazone reduces microalbuminuria and blood pressure independently of glycemia in type 2 diabetes patients with microalbuminuria. J Hypertens. 2006;24(10): 2047-2055.

74. Kodera R, Shikata K, Takatsuka T, et al. Dipeptidyl peptidase-4 inhibitor ameliorates early renal injury through its anti-inflammatory action in a rat model of type 1 diabetes. Biochem Biophys Res Commun. 2014; 443(3):828-833.

75. Mori H, Okada Y, Arao T, Tanaka Y. Sitagliptin improves albuminuria in patients with type 2 diabetes mellitus. J Diabetes Investig. 2014;5(3): 313-319.

76. Fujita H, Taniai H, Murayama H, et al. DPP-4 inhibition with alogliptin on top of angiotensin II type 1 receptor blockade ameliorates albuminuria via up-regulation of SDF- $1 \alpha$ in type 2 diabetic patients with incipient nephropathy. Endocr J. 2014;61(2):159-166.

77. Cherney DZ, Perkins BA, Soleymanlou N, et al. Renal hemodynamic effect of sodium-glucose cotransporter 2 inhibition in patients with type 1 diabetes mellitus. Circulation. 2014;129(5):587-597.

78. Viberti G, Mogensen CE, Groop LC, Pauls JF; European Microalbuminuria Captopril Study Group. Effect of captopril on progression to clinical proteinuria in patients with insulin-dependent diabetes mellitus and microalbuminuria. JAMA. 1994;271(4):275-279.

79. The Microalbuminuria Captopril Study Group. Captopril reduces the risk of nephropathy in IDDM patients with microalbuminuria. Diabetologia. 1996;39(5):587-593.

80. Lewis EJ, Hunsicker LG, Bain RP, Rohde RD; The Collaborative Study Group. The effect of angiotensin-converting-enzyme inhibition on diabetic nephropathy. $N$ Engl J Med. 1993;329(20):1456-1462.

81. Wilmer WA, Hebert LA, Lewis EJ, et al. Remission of nephrotic syndrome in type 1 diabetes: long-term follow-up of patients in the Captopril Study. Am J Kidney Dis. 1999;34(2):308-314.

82. Hovind P, Rossing P, Tarnow L, Toft H, Parving J, Parving HH. Remission of nephrotic-range albuminuria in type 1 diabetic patients. Diabetes Care. 2001;24(11):1972-1977.

83. Hovind P, Tarnow L, Rossing P, Carstensen B, Parving HH. Improved survival in patients obtaining remission of nephrotic range albuminuria in diabetic nephropathy. Kidney Int. 2004;66(3):1180-1186.

84. de Galan BE, Zoungas S, Chalmers J, et al. Cognitive function and risks of cardiovascular disease and hypoglycaemia in patients with type 2 diabetes: the Action in Diabetes and Vascular Disease: Preterax and Diamicron Modified Release Controlled Evaluation (ADVANCE) trial. Diabetologia. 2009;52(11):2328-2336.

85. Ruggenenti P, Fassi A, Ilieva AP, et al. Preventing microalbuminuria in type 2 diabetes. $N$ Engl J Med. 2004;351(19):1941-1951.

86. Lewis EJ, Hunsicker LG, Clarke WR, et al. Renoprotective effect of the angiotensin-receptor antagonist irbesartan in patients with nephropathy due to type 2 diabetes. $N$ Engl J Med. 2001;345(12):851-860.

87. Brenner BM, Cooper ME, de Zeeuw D, et al. Effects of losartan on renal and cardiovascular outcomes in patients with type 2 diabetes and nephropathy. N Engl J Med. 2001;345(12):861-869. 
88. Eijkelkamp WB, Zhang Z, Remuzzi G, et al. Albuminuria is a target for renoprotective therapy independent from blood pressure in patients with type 2 diabetic nephropathy: post hoc analysis from the Reduction of Endpoints in NIDDM with the Angiotensin II Antagonist Losartan (RENAAL) trial. J Am Soc Nephrol. 2007;18(5):1540-1546.

89. Haller $\mathrm{H}$, Ito S, Izzo JL Jr, et al. Olmesartan for the delay or prevention of microalbuminuria in type 2 diabetes. N Engl J Med. 2011;364(10): 907-917.

90. Barnett AH, Bain SC, Bouter P, et al. Angiotensin-receptor blockade versus converting-enzyme inhibition in type 2 diabetes and nephropathy. N Engl J Med. 2004;351(19):1952-1961.

91. Lv J, Perkovic V, Foote CV, Craig ME, Craig JC, Strippoli GF. Antihypertensive agents for preventing diabetic kidney disease [review]. Cochrane Database Syst Rev. 2012;12:CD004136.

92. Jacobsen P, Andersen S, Rossing K, Jensen BR, Parving HH. Dual blockade of the renin-angiotensin system versus maximal recommended dose of ACE inhibition in diabetic nephropathy. Kidney Int. 2003;63(5):1874-1880.

93. Jacobsen P, Andersen S, Jensen BR, Parving HH. Additive effect of ACE inhibition and angiotensin II receptor blockade in type I diabetic patients with diabetic nephropathy. J Am Soc Nephrol. 2003;14(4): 992-999.

94. Mogensen CE, Neldam S, Tikkanen I, et al. Randomised controlled trial of dual blockade of renin-angiotensin system in patients with hypertension, microalbuminuria, and non-insulin dependent diabetes: the candesartan and lisinopril microalbuminuria (CALM) study. BMJ. 2000;321(7274):1440-1444.

95. Song JH, Cha SH, Lee HJ, et al. Effect of low-dose dual blockade of renin-angiotensin system on urinary TGF-beta in type 2 diabetic patients with advanced kidney disease. Nephrol Dial Transplant. 2006;21(3):683-689.

96. Mann JF, Anderson C, Gao P, et al. Dual inhibition of the reninangiotensin system in high-risk diabetes and risk for stroke and other outcomes: results of the ONTARGET trial. J Hypertens. 2013;31(2): 414-421.

97. Fried LF, Emanuele N, Zhang JH, et al. Combined angiotensin inhibition for the treatment of diabetic nephropathy. $N$ Engl $J$ Med. 2013;369(20):1892-1903.

98. Wolf G. Renal injury due to renin-angiotensin-aldosterone system activation of the transforming growth factor-beta pathway. Kidney Int. 2006;70(11):1914-1919.

99. Huang W, Xu C, Kahng KW, Noble NA, Border WA, Huang Y. Aldosterone and TGF-betal synergistically increase PAI-1 and decrease matrix degradation in rat renal mesangial and fibroblast cells. Am J Physiol Renal Physiol. 2008;294(6):F1287-F1295.

100. Schjoedt KJ, Rossing K, Juhl TR, et al. Beneficial impact of spironolactone in diabetic nephropathy. Kidney Int. 2005;68(6):2829-2836.

101. Rossing K, Schjoedt KJ, Smidt UM, Boomsma F, Parving HH. Beneficial effects of adding spironolactone to recommended antihypertensive treatment in diabetic nephropathy: a randomized, doublemasked, cross-over study. Diabetes Care. 2005;28(9):2106-2112.

102. Han SY, Kim CH, Kim HS, et al. Spironolactone prevents diabetic nephropathy through an anti-inflammatory mechanism in type 2 diabetic rats. J Am Soc Nephrol. 2006;17(5):1362-1372.

103. Epstein M, Williams GH, Weinberger M, et al. Selective aldosterone blockade with eplerenone reduces albuminuria in patients with type 2 diabetes. Clin J Am Soc Nephrol. 2006;1(5):940-951.

104. Bakris GL, Copley JB, Vicknair N, Sadler R, Leurgans S. Calcium channel blockers versus other antihypertensive therapies on progression of NIDDM associated nephropathy. Kidney Int. 1996;50(5): 1641-1650.

105. Bakris GL, Barnhill BW, Sadler R. Treatment of arterial hypertension in diabetic humans: importance of therapeutic selection. Kidney Int. 1992;41(4):912-919.

106. Bakris GL, Weir MR, DeQuattro V, McMahon FG. Effects of an ACE inhibitor/calcium antagonist combination on proteinuria in diabetic nephropathy. Kidney Int. 1998;54(4):1283-1289.
107. Ruggenenti P, Fassi A, Ilieva A, et al. Effects of verapamil added-on trandolapril therapy in hypertensive type 2 diabetes patients with microalbuminuria: the BENEDICT-B randomized trial. J Hypertens. 2011;29(2):207-216.

108. Viberti G, Wheeldon NM. Microalbuminuria reduction with valsartan in patients with type 2 diabetes mellitus: a blood pressure-independent effect. Circulation. 2002;106(6):672-678.

109. Herlitz H, Harris K, Risler T, et al. The effects of an ACE inhibitor and a calcium antagonist on the progression of renal disease: the Nephros Study. Nephrol Dial Transplant. 2001;16(11):2158-2165.

110. Ruggenenti P, Perna A, Loriga G, et al. Blood-pressure control for renoprotection in patients with non-diabetic chronic renal disease (REIN-2): multicentre, randomised controlled trial. Lancet. 2005;365(9463):939-946.

111. James PA, Oparil S, Carter BL, et al. 2014 evidence-based guideline for the management of high blood pressure in adults: report from the panel members appointed to the Eighth Joint National Committee (JNC 8). JAMA. 2014;311(5):507-520.

112. Mancia G, Fagard R, Narkiewicz K, et al. 2013 ESH/ESC guidelines for the management of arterial hypertension: the task force for the management of arterial hypertension of the European Society of Hypertension (ESH) and of the European Society of Cardiology (ESC). J Hypertens. 2013;31(7):1281-1357.

113. Pilmore H, Dogra G, Roberts M, et al. Cardiovascular disease in patients with chronic kidney disease. Nephrology (Carlton). 2014; 19(1):3-10.

114. National Kidney Foundation. KDOQI clinical practice guideline for diabetes and CKD: 2012 update. Am J Kidney Dis. 2012;60(5): $850-886$.

115. Ruzicka M, Quinn RR, McFarlane P, et al. Canadian Society of Nephrology commentary on the 2012 KDIGO clinical practice guideline for the management of blood pressure in CKD. Am J Kidney Dis. 2014;63(6):869-887.

116. Sacks FM, Hermans MP, Fioretto P, et al. Association between plasma triglycerides and high-density lipoprotein cholesterol and microvascular kidney disease and retinopathy in type 2 diabetes mellitus: a global case-control study in 13 countries. Circulation. 2014;129(9): 999-1008.

117. Krolewski AS, Warram JH, Christlieb AR. Hypercholesterolemia a determinant of renal function loss and deaths in IDDM patients with nephropathy. Kidney Int Suppl. 1994;45:S125-131.

118. Ishibashi Y, Yamagishi S, Matsui T, et al. Pravastatin inhibits advanced glycation end products (AGEs)-induced proximal tubular cell apoptosis and injury by reducing receptor for AGEs (RAGE) level. Metabolism. 2012;61(8):1067-1072.

119. Gao P, Wu X, Shui H, Jia R. Fluvastatin inhibits high glucose-induced nuclear factor kappa B activation in renal tubular epithelial cells. J Nephrol. 2013;26(2):289-296.

120. Toba H, Mitani T, Takahashi T, et al. Inhibition of the renal renin-angiotensin system and renoprotection by pitavastatin in type 1 diabetes. Clin Exp Pharmacol Physiol. 2010;37(11):1064-1070.

121. Tonolo G, Velussi M, Brocco E, et al. Simvastatin maintains steady patterns of GFR and improves AER and expression of slit diaphragm proteins in type II diabetes. Kidney Int. 2006;70(1):177-186.

122. Abe M, Maruyama N, Okada K, Matsumoto S, Matsumoto K, Soma M. Effects of lipid-lowering therapy with rosuvastatin on kidney function and oxidative stress in patients with diabetic nephropathy. J Atheroscler Thromb. 2011;18(11):1018-1028.

123. Collins R, Armitage J, Parish S, Sleigh P, Peto R; Heart Protection Study Collaborative Group. MRC/BHF Heart Protection Study of cholesterol lowering with simvastatin in 5963 people with diabetes: a randomised placebo-controlled trial. Lancet. 2003;361 (9374): 2005-2016.

124. Colhoun HM, Betteridge DJ, Durrington PN, et al. Effects of atorvastatin on kidney outcomes and cardiovascular disease in patients with diabetes: an analysis from the Collaborative Atorvastatin Diabetes Study (CARDS). Am J Kidney Dis. 2009;54(5):810-819. 
125. Gerstein HC, Mann JF, Yi Q, et al. Albuminuria and risk of cardiovascular events, death, and heart failure in diabetic and nondiabetic individuals. JAMA. 2001;286(4):421-426.

126. Ficociello LH, Rosolowsky ET, Niewczas MA, et al. High-normal serum uric acid increases risk of early progressive renal function loss in type 1 diabetes: results of a 6-year follow-up. Diabetes Care. 2010; 33(6):1337-1343

127. Jalal DI, Rivard CJ, Johnson RJ, et al. Serum uric acid levels predict the development of albuminuria over 6 years in patients with type 1 diabetes: findings from the Coronary Artery Calcification in Type 1 Diabetes study. Nephrol Dial Transplant. 2010;25(6):1865-1869.

128. Hovind P, Rossing P, Tarnow L, Johnson RJ, Parving HH. Serum uric acid as a predictor for development of diabetic nephropathy in type 1 diabetes: an inception cohort study. Diabetes. 2009;58(7):1668-1671.

129. Miao Y, Ottenbros SA, Laverman GD, et al. Effect of a reduction in uric acid on renal outcomes during losartan treatment: a post hoc analysis of the reduction of endpoints in non-insulin-dependent diabetes mellitus with the Angiotensin II Antagonist Losartan Trial. Hypertension. 2011;58(1):2-7.

130. Kim SM, Choi YW, Seok HY, et al. Reducing serum uric acid attenuates TGF- $\beta 1$-induced profibrogenic progression in type 2 diabetic nephropathy. Nephron Exp Nephrol. 2012;121(3-4):e109-e121.

131. Kosugi T, Nakayama T, Heinig M, et al. Effect of lowering uric acid on renal disease in the type 2 diabetic $\mathrm{db} / \mathrm{db}$ mice. Am J Physiol Renal Physiol. 2009;297(2):F481-F488.

132. Dogan A, Yarlioglues M, Kaya MG, et al. Effect of long-term and high-dose allopurinol therapy on endothelial function in normotensive diabetic patients. Blood Press. 2011;20(3):182-187.

133. Butler R, Morris AD, Belch JJ, Hill A, Struthers AD. Allopurinol normalizes endothelial dysfunction in type 2 diabetics with mild hypertension. Hypertension. 2000;35(3):746-751.

134. Talaat KM, el-Sheikh AR. The effect of mild hyperuricemia on urinary transforming growth factor beta and the progression of chronic kidney disease. Am J Nephrol. 2007;27(5):435-440.

135. Maahs DM, Caramori L, Cherney DZ, et al. Uric acid lowering to prevent kidney function loss in diabetes: the Preventing Early Renal Function Loss (PERL) allopurinol study. Curr Diab Rep. 2013;13(4): $550-559$.

136. Zhang Z, Zhang Y, Ning G, Deb DK, Kong J, Li YC. Combination therapy with AT1 blocker and vitamin D analog markedly ameliorates diabetic nephropathy: blockade of compensatory renin increase. Proc Natl Acad Sci U S A. 2008;105(41):15896-15901.

137. Wang Y, Deb DK, Zhang Z, et al. Vitamin D receptor signaling in podocytes protects against diabetic nephropathy. J Am Soc Nephrol. 2012;23(12):1977-1986.

138. Xiong M, Gong J, Liu Y, Xiang R, Tan X. Loss of vitamin D receptor in chronic kidney disease: a potential mechanism linking inflammation to epithelial-to-mesenchymal transition. Am J Physiol Renal Physiol. 2012;303(7):F1107-F1115.

139. Nakai K, Fujii H, Kono K, et al. Vitamin D activates the Nrf2-Keap1 antioxidant pathway and ameliorates nephropathy in diabetic rats. Am J Hypertens. 2014;27(4):586-595.

140. Fernandez-Juarez G, Luno J, Barrio V, et al. $25(\mathrm{OH})$ vitamin D levels and renal disease progression in patients with type 2 diabetic nephropathy and blockade of the renin-angiotensin system. Clin J Am Soc Nephrol. 2013;8(11):1870-1876.

141. de Zeeuw D, Agarwal R, Amdahl M, et al. Selective vitamin D receptor activation with paricalcitol for reduction of albuminuria in patients with type 2 diabetes (VITAL study): a randomised controlled trial. Lancet. 2010;376(9752):1543-1551.

142. Brown JM, Secinaro K, Williams JS, Vaidya A. Evaluating hormonal mechanisms of vitamin D receptor agonist therapy in diabetic kidney disease: the VALIDATE-D study. BMC Endocr Disord. 2013;13(1):33.

143. Makura CB, Nirantharakumar K, Girling AJ, Saravanan P, Narendran P. Effects of physical activity on the development and progression of microvascular complications in type 1 diabetes: retrospective analysis of the DCCT study. BMC Endocr Disord. 2013;13(1):37.
144. Wing RR, Bolin P, Brancati FL, et al. Cardiovascular effects of intensive lifestyle intervention in type 2 diabetes. $N$ Engl J Med. 2013;369(2): $145-154$

145. Nezu U, Kamiyama H, KondoY, Sakuma M, Morimoto T, Ueda S. Effect of low-protein diet on kidney function in diabetic nephropathy: meta-analysis of randomised controlled trials. BMJ Open. 2013;3(5): e002934.

146. Anderson JW. Beneficial effects of soy protein consumption for renal function. Asia Pac J Clin Nutr. 2008;17(Suppl 1):324-328.

147. Kwakernaak AJ, Krikken JA, Binnenmars SH, et al. Effects of sodium restriction and hydrochlorothiazide on RAAS blockade efficacy in diabetic nephropathy: a randomised clinical trial. Lancet Diabetes Endocrinol. 2014;2(5):385-395.

148. Houlihan CA, Allen TJ, Baxter AL, et al. A low-sodium diet potentiates the effects of losartan in type 2 diabetes. Diabetes Care. 2002;25(4): 663-671.

149. Pedersen O, Gaede P. Intensified multifactorial intervention and cardiovascular outcome in type 2 diabetes: the Steno-2 study. Metabolism. 2003;52(8 Suppl 1):19-23.

150. Bohman SO, Tyden G, Wilczek H, et al. Prevention of kidney graft diabetic nephropathy by pancreas transplantation in man. Diabetes. 1985;34(3):306-308.

151. Bilous RW, Mauer SM, Sutherland DE, Najarian JS, Goetz FC, Steffes MW. The effects of pancreas transplantation on the glomerular structure of renal allografts in patients with insulin-dependent diabetes. N Engl J Med. 1989;321(2):80-85.

152. Fioretto P, Steffes MW, Sutherland DE, Goetz FC, Mauer M. Reversal of lesions of diabetic nephropathy after pancreas transplantation. N Engl J Med. 1998;339(2):69-75.

153. Fioretto P, Sutherland DE, Najafian B, Mauer M. Remodeling of renal interstitial and tubular lesions in pancreas transplant recipients. Kidney Int. 2006;69(5):907-912.

154. Kelly DJ, Zhang Y, Moe G, Naik G, Gilbert RE. Aliskiren, a novel renin inhibitor, is renoprotective in a model of advanced diabetic nephropathy in rats. Diabetologia. 2007;50(11):2398-2404.

155. Persson F, Rossing P, Schjoedt KJ, et al. Time course of the antiproteinuric and antihypertensive effects of direct renin inhibition in type 2 diabetes. Kidney Int. 2008;73(12):1419-1425.

156. Parving HH, Persson F, Lewis JB, Lewis EJ, Hollenberg NK. Aliskiren combined with losartan in type 2 diabetes and nephropathy. $N$ Engl J Med. 2008;358(23):2433-2446.

157. Parving HH, Brenner BM, McMurray JJ, et al. Cardiorenal end points in a trial of aliskiren for type 2 diabetes. N Engl J Med. 2012;367(23): 2204-2213.

158. Sasser JM, Sullivan JC, Hobbs JL, et al. Endothelin A receptor blockade reduces diabetic renal injury via an anti-inflammatory mechanism. J Am Soc Nephrol. 2007;18(1):143-154.

159. Gagliardini E, Corna D, Zoja C, et al. Unlike each drug alone, lisinopril if combined with avosentan promotes regression of renal lesions in experimental diabetes. Am J Physiol Renal Physiol. 2009;297(5): F1448-F1456.

160. Mann JF, Green D, Jamerson K, et al. Avosentan for overt diabetic nephropathy. J Am Soc Nephrol. 2010;21(3):527-535.

161. Wenzel RR, Littke T, Kuranoff S, et al. Avosentan reduces albumin excretion in diabetics with macroalbuminuria. J Am Soc Nephrol. 2009;20(3):655-664.

162. de Zeeuw D, Coll B, Andress D, et al. The endothelin antagonist atrasentan lowers residual albuminuria in patients with type 2 diabetic nephropathy. J Am Soc Nephrol. 2014;25(5):1083-1093.

163. Sidharta PN, Wagner FD, Bohnemeier H, et al. Pharmacodynamics and pharmacokinetics of the urotensin II receptor antagonist palosuran in macroalbuminuric, diabetic patients. Clin Pharmacol Ther. 2006;80(3):246-256.

164. Vogt L, Chiurchiu C, Chadha-Boreham H, et al. Effect of the urotensin receptor antagonist palosuran in hypertensive patients with type 2 diabetic nephropathy. Hypertension. 2010;55(5):1206-1209.

165. Schafer S, Linz W, Vollert H, et al. The vasopeptidase inhibitor AVE7688 ameliorates type 2 diabetic nephropathy. Diabetologia. 2004;47(1):98-103. 
166. Davis BJ, Johnston CI, Burrell LM, et al. Renoprotective effects of vasopeptidase inhibition in an experimental model of diabetic nephropathy. Diabetologia. 2003;46(7):961-971.

167. Koya D, Haneda M, Nakagawa H, et al. Amelioration of accelerated diabetic mesangial expansion by treatment with a PKC beta inhibitor in diabetic $\mathrm{db} / \mathrm{db}$ mice, a rodent model for type 2 diabetes. FASEB J. 2000;14(3):439-447.

168. Wu Y, Wu G, Qi X, et al. Protein kinase C beta inhibitor LY333531 attenuates intercellular adhesion molecule-1 and monocyte chemotactic protein-1 expression in the kidney in diabetic rats. J Pharmacol Sci. 2006;101(4):335-343.

169. Gilbert RE, Kim SA, Tuttle KR, et al. Effect of ruboxistaurin on urinary transforming growth factor-beta in patients with diabetic nephropathy and type 2 diabetes. Diabetes Care. 2007;30(4):995-996.

170. Tuttle KR, Bakris GL, Toto RD, McGill JB, Hu K, Anderson PW. The effect of ruboxistaurin on nephropathy in type 2 diabetes. Diabetes Care. 2005;28(11):2686-2690.

171. Tuttle KR, McGill JB, Haney DJ, Lin TE, Anderson PW. Kidney outcomes in long-term studies of ruboxistaurin for diabetic eye disease. Clin J Am Soc Nephrol. 2007;2(4):631-636.

172. Itagaki I, Shimizu K, Kamanaka Y, et al. The effect of an aldose reductase inhibitor (epalrestat) on diabetic nephropathy in rats. Diabetes Res Clin Pract. 1994;25(3):147-154.

173. Donnelly SM, Zhou XP, Huang JT, Whiteside CI. Prevention of early glomerulopathy with tolrestat in the streptozotocin-induced diabetic rat. Biochem Cell Biol. 1996;74(3):355-362.

174. Iso K, Tada H, Kuboki K, Inokuchi T. Long-term effect of epalrestat, an aldose reductase inhibitor, on the development of incipient diabetic nephropathy in type 2 diabetic patients. $J$ Diabetes Complications. 2001;15(5):241-244.

175. Hotta N, Kawamori R, Fukuda M, Shigeta Y. Long-term clinical effects of epalrestat, an aldose reductase inhibitor, on progression of diabetic neuropathy and other microvascular complications: multivariate epidemiological analysis based on patient background factors and severity of diabetic neuropathy. Diabet Med. 2012;29(12):1529-1533.

176. Ranganathan S, Krempf M, Feraille E, Charbonnel B. Short term effect of an aldose reductase inhibitor on urinary albumin excretion rate (UAER) and glomerular filtration rate (GFR) in type 1 diabetic patients with incipient nephropathy. Diabete Metab. 1993;19(2):257-261.

177. Wang X, Yan L, Chen W, Xu L, Zhang X. The renal protective effects of cilostazol on suppressing pathogenic thrombospondin-1 and transforming growth factor-beta expression in streptozotocin-induced diabetic rats. J Int Med Res. 2009;37(1):145-153.

178. Tohma T, Shimabukuro M, Oshiro Y, Yamakawa M, ShimajiriY, Takasu N. Cilostazol, a phosphodiesterase inhibitor, reduces microalbuminuria in the insulin-resistant Otsuka Long-Evans Tokushima Fatty rat. Metabolism. 2004;53(11):1405-1410.

179. Watanabe J, Sako Y, Umeda F, Nawata H. Effects of cilostazol, a phosphodiesterase inhibitor, on urinary excretion of albumin and prostaglandins in non-insulin-dependent diabetic patients. Diabetes Res Clin Pract. 1993;22(1):53-59.

180. Jiao XM, Jiao XJ, Zhang XG, et al. Cilostazol reduces microalbuminuria in type 2 diabetic nephropathy. Chin Med J (Engl). 2013;126(22): 4395-4396.

181. Shan D, Wu HM, Yuan QY, Li J, Zhou RL, Liu GJ. Pentoxifylline for diabetic kidney disease [review]. Cochrane Database Syst Rev. 2012;2:CD006800.

182. Roozbeh J, Banihashemi MA, Ghezlou M, et al. Captopril and combination therapy of captopril and pentoxifylline in reducing proteinuria in diabetic nephropathy. Ren Fail. 2010;32(2):172-178.

183. Oliaei F, Hushmand S, Khafri S, Baradaran M. Efficacy of pentoxifylline for reduction of proteinuria in type II diabetic patients. Caspian J Intern Med. 2011;2(4):309-313.

184. Ghorbani A, Omidvar B, Beladi-Mousavi SS, Lak E, Vaziri S. The effect of pentoxifylline on reduction of proteinuria among patients with type 2 diabetes under blockade of angiotensin system: a double blind and randomized clinical trial. Nefrologia. 2012;32(6):790-796.
185. Navarro-Gonzalez JF, Muros M, Mora-Fernandez C, Herrera H, Meneses B, Garcia J. Pentoxifylline for renoprotection in diabetic nephropathy: the PREDIAN study. Rationale and basal results. J Diabetes Complications. 2011;25(5):314-319.

186. Thornalley PJ. Use of aminoguanidine (pimagedine) to prevent the formation of advanced glycation endproducts. Arch Biochem Biophys. 2003;419(1):31-40.

187. Soulis-Liparota T, Cooper M, Papazoglou D, Clarke B, Jerums G. Retardation by aminoguanidine of development of albuminuria, mesangial expansion, and tissue fluorescence in streptozocin-induced diabetic rat. Diabetes. 1991;40(10):1328-1334.

188. Bolton WK, Cattran DC, Williams ME, et al. Randomized trial of an inhibitor of formation of advanced glycation end products in diabetic nephropathy. Am J Nephrol. 2004;24(1):32-40.

189. Williams ME, Bolton WK, Khalifah RG, Degenhardt TP, Schotzinger RJ, McGill JB. Effects of pyridoxamine in combined Phase II studies of patients with type 1 and type 2 diabetes and overt nephropathy. Am J Nephrol. 2007;27(6):605-614.

190. Lewis EJ, Greene T, Spitalewiz S, et al. Pyridorin in type 2 diabetic nephropathy. J Am Soc Nephrol. 2012;23(1):131-136.

191. Kennedy L, Solano MP, Meneghini L, Lo M, Cohen MP. Anti-glycation and anti-albuminuric effects of GLY-230 in human diabetes. Am J Nephrol. 2010;31(2):110-116.

192. Ruiz S, Pergola PE, Zager RA, Vaziri ND. Targeting the transcription factor Nrf2 to ameliorate oxidative stress and inflammation in chronic kidney disease. Kidney Int. 2013;83(6):1029-1041.

193. Pergola PE, Raskin P, Toto RD, et al. Bardoxolone methyl and kidney function in CKD with type 2 diabetes. $N$ Engl J Med. 2011;365(4): 327-336.

194. de Zeeuw D, Akizawa T, Audhya P, et al. Bardoxolone methyl in type 2 diabetes and stage 4 chronic kidney disease. $N$ Engl J Med. 2013;369(26):2492-2503.

195. Zoja C, Corna D, Nava V, et al. Analogs of bardoxolone methyl worsen diabetic nephropathy in rats with additional adverse effects. Am J Physiol Renal Physiol. 2013;304(6):F808-F819.

196. Ciszewicz M, Polubinska A, Antoniewicz A, Suminska-Jasinska K, Breborowicz A. Sulodexide suppresses inflammation in human endothelial cells and prevents glucose cytotoxicity. Transl Res. 2009;153(3):118-123

197. Masola V, Zaza G, Gambaro G. Sulodexide and glycosaminoglycans in the progression of renal disease. Nephrol Dial Transplant. 2014;29(Suppl 1):i74-i79.

198. Gambaro G, Kinalska I, Oksa A, et al. Oral sulodexide reduces albuminuria in microalbuminuric and macroalbuminuric type 1 and type 2 diabetic patients: the DiNAS randomized trial. J Am Soc Nephrol. 2002;13(6):1615-1625.

199. Lewis EJ, Lewis JB, Greene T, et al. Sulodexide for kidney protection in type 2 diabetes patients with microalbuminuria: a randomized controlled trial. Am J Kidney Dis. 2011;58(5):729-736.

200. Packham DK, Wolfe R, Reutens AT, et al. Sulodexide fails to demonstrate renoprotection in overt type 2 diabetic nephropathy. J Am Soc Nephrol. 2012;23(1):123-130.

201. RamachandraRao SP, Zhu Y, Ravasi T, et al. Pirfenidone is renoprotective in diabetic kidney disease. J Am Soc Nephrol. 2009;20(8):1765-1775.

202. Ka SM, Yeh YC, Huang XR, et al. Kidney-targeting Smad7 gene transfer inhibits renal TGF- $\beta$ /MAD homologue (SMAD) and nuclear factor $\kappa \mathrm{B}(\mathrm{NF}-\kappa \mathrm{B})$ signalling pathways, and improves diabetic nephropathy in mice. Diabetologia. 2012;55(2):509-519.

203. Zhang Z, Wu F, Zheng F, Li H. Adenovirus-mediated decorin gene transfection has therapeutic effects in a streptozocin-induced diabetic rat model. Nephron Exp Nephrol. 2010;116(1):e11-e21.

204. Flaquer M, Franquesa M, Vidal A, et al. Hepatocyte growth factor gene therapy enhances infiltration of macrophages and may induce kidney repair in $\mathrm{db} / \mathrm{db}$ mice as a model of diabetes. Diabetologia. 2012;55(7):2059-2068.

205. Kosugi T, Nakayama T, Li Q, et al. Soluble Flt-1 gene therapy ameliorates albuminuria but accelerates tubulointerstitial injury in diabetic mice. Am J Physiol Renal Physiol. 2010;298(3):F609-F616. 
206. Li D, Wang N, Zhang L, et al. Mesenchymal stem cells protect podocytes from apoptosis induced by high glucose via secretion of epithelial growth factor. Stem Cell Res Ther. 2013;4(5):103.

207. Zhang Y, Yuen DA, Advani A, et al. Early-outgrowth bone marrow cells attenuate renal injury and dysfunction via an antioxidant effect in a mouse model of type 2 diabetes. Diabetes. 2012;61(8):2114-2125.

208. Sabbisetti VS, Waikar SS, Antoine DJ, et al. Blood kidney injury molecule-1 is a biomarker of acute and chronic kidney injury and predicts progression to ESRD in type I diabetes. J Am Soc Nephrol. Epub June 5, 2014.

209. Nielsen SE, Andersen S, Zdunek D, Hess G, Parving HH, Rossing P. Tubular markers do not predict the decline in glomerular filtration rate in type 1 diabetic patients with overt nephropathy. Kidney Int. 2011; 79(10):1113-1118.

210. Conway BR, Manoharan D, Jenks S, et al. Measuring urinary tubular biomarkers in type 2 diabetes does not add prognostic value beyond established risk factors. Kidney Int. 2012;82(7):812-818.

211. Lacquaniti A, Donato V, Pintaudi B, et al. "Normoalbuminuric" diabetic nephropathy: tubular damage and NGAL. Acta Diabetol. 2013;50(6):935-942.

212. Chou KM, Lee CC, Chen CH, Sun CY. Clinical value of NGAL, L-FABP, and albuminuria in predicting GFR decline in type 2 diabetes mellitus patients. PLoS One. 2013;8(1):e54863.

213. Panduru NM, Forsblom C, Saraheimo M, et al. Urinary liver-type fatty acid-binding protein and progression of diabetic nephropathy in type 1 diabetes. Diabetes Care. 2013;36(7):2077-2083.

214. Nielsen SE, Sugaya T, Hovind P, Baba T, Parving HH, Rossing P. Urinary liver-type fatty acid-binding protein predicts progression to nephropathy in type 1 diabetic patients. Diabetes Care. 2010;33(6): $1320-1324$

215. Araki S, Haneda M, Koya D, et al. Predictive effects of urinary livertype fatty acid-binding protein for deteriorating renal function and incidence of cardiovascular disease in type 2 diabetic patients without advanced nephropathy. Diabetes Care. 2013;36(5):1248-1253.

216. Kamijo-Ikemori A, Sugaya T, Yasuda T, et al. Clinical significance of urinary liver-type fatty acid-binding protein in diabetic nephropathy of type 2 diabetic patients. Diabetes Care. 2011;34(3):691-696.

217. Kim SS, Song SH, Kim IJ, et al. Urinary cystatin C and tubular proteinuria predict progression of diabetic nephropathy. Diabetes Care 2013;36(3):656-661.

218. Fallahzadeh MK, Dormanesh B, Sagheb MM, et al. Effect of addition of silymarin to renin-angiotensin system inhibitors on proteinuria in type 2 diabetic patients with overt nephropathy: a randomized, double-blind, placebo-controlled trial. Am J Kidney Dis. 2012;60(6):896-903.

219. Khan MI, Siddique KU, Ashfaq F, Ali W, Reddy HD, Mishra A. Effect of high-dose zinc supplementation with oral hypoglycemic agents on glycemic control and inflammation in type-2 diabetic nephropathy patients. J Nat Sci Biol Med. 2013;4(2):336-340.

220. Parham M, Amini M, Aminorroaya A, Heidarian E. Effect of zinc supplementation on microalbuminuria in patients with type 2 diabetes: a double blind, randomized, placebo-controlled, cross-over trial. Rev Diabet Stud. 2008;5(2):102-109.
221. Khajehdehi P, Pakfetrat M, Javidnia K, et al. Oral supplementation of turmeric attenuates proteinuria, transforming growth factor-beta and interleukin- 8 levels in patients with overt type 2 diabetic nephropathy: a randomized, double-blind and placebo-controlled study. Scand J Urol Nephrol. 2011;45(5):365-370.

222. Rossing P, Hansen BV, Nielsen FS, Myrup B, Holmer G, Parving HH. Fish oil in diabetic nephropathy. Diabetes Care. 1996; 19(11):1214-1219.

223. Lee RH, Seo MJ, Reger RL, et al. Multipotent stromal cells from human marrow home to and promote repair of pancreatic islets and renal glomeruli in diabetic NOD/scid mice. Proc Natl Acad Sci US A. 2006;103(46):17438-17443.

224. Ezquer FE, Ezquer ME, Parrau DB, Carpio D, Yanez AJ, Conget PA. Systemic administration of multipotent mesenchymal stromal cells reverts hyperglycemia and prevents nephropathy in type 1 diabetic mice. Biol Blood Marrow Transplant. 2008;14(6):631-640.

225. Ezquer F, Ezquer M, Simon V, et al. Endovenous administration of bone-marrow-derived multipotent mesenchymal stromal cells prevents renal failure in diabetic mice. Biol Blood Marrow Transplant. 2009;15(11):1354-1365.

226. Zhou H, Tian HM, Long Y, et al. Mesenchymal stem cells transplantation mildly ameliorates experimental diabetic nephropathy in rats. Chin Med J (Engl). 2009;122(21):2573-2579.

227. Park JH, Park J, Hwang SH, Han H, Ha H. Delayed treatment with human umbilical cord blood-derived stem cells attenuates diabetic renal injury. Transplant Proc. 2012;44(4):1123-1126.

228. Park JH, Hwang I, Hwang SH, Han H, Ha H. Human umbilical cord blood-derived mesenchymal stem cells prevent diabetic renal injury through paracrine action. Diabetes Res Clin Pract. 2012;98(3): 465-473.

229. Fang Y, Tian X, Bai S, et al. Autologous transplantation of adiposederived mesenchymal stem cells ameliorates streptozotocin-induced diabetic nephropathy in rats by inhibiting oxidative stress, proinflammatory cytokines, and the p38 MAPK signaling pathway. Int $J$ Mol Med. 2012;30(1):85-92.

230. Wang S, LiY, Zhao J, Zhang J, Huang Y. Mesenchymal stem cells ameliorate podocyte injury and proteinuria in a type 1 diabetic nephropathy rat model. Biol Blood Marrow Transplant. 2013;19(4):538-546.

231. Lv SS, Liu G, Wang JP, et al. Mesenchymal stem cells transplantation ameliorates glomerular injury in streptozotocin-induced diabetic nephropathy in rats via inhibiting macrophage infiltration. Int Immunopharmacol. 2013;17(2):275-282.

232. Zhang Y, Ye C, Wang G, et al. Kidney-targeted transplantation of mesenchymal stem cells by ultrasound-targeted microbubble destruction promotes kidney repair in diabetic nephropathy rats. Biomed Res Int. 2013;2013:526367.

233. Zhang L, Li K, Liu X, et al. Repeated systemic administration of human adipose-derived stem cells attenuates overt diabetic nephropathy in rats. Stem Cells Dev. 2013;22(23):3074-3086.

234. Abdel Aziz MT, Wassef MA, Ahmed HH, et al. The role of bone marrow derived-mesenchymal stem cells in attenuation of kidney function in rats with diabetic nephropathy. Diabetol Metab Syndr. 2014;6(1):34.

International Journal of Nephrology and Renovascular Disease

\section{Publish your work in this journal}

The International Journal of Nephrology and Renovascular Disease is an international, peer-reviewed open-access journal focusing on the pathophysiology of the kidney and vascular supply. Epidemiology, screening, diagnosis, and treatment interventions are covered as well as basic science, biochemical and immunological studies. The journal welcomes original research, clinical studies, reviews \& evaluations, expert opinion and commentary, case reports and extended reports. The manuscript management system is completely online and includes a very quick and fair peerreview system, which is all easy to use. Visit http://www.dovepress.com/ testimonials.php to read real quotes from published authors. 